\title{
Temperature-dependent rate coefficients for the reactions of the hydroxyl radical with the atmospheric biogenics isoprene, alpha-pinene and delta-3-carene
}

\author{
Terry J. Dillon ${ }^{1, a}$, Katrin Dulitz ${ }^{1, b}$, Christoph B. M. Groß ${ }^{1}$, and John N. Crowley ${ }^{1}$ \\ ${ }^{1}$ Department of Air Chemistry, Max Planck Institute for Chemistry, 55128 Mainz, Germany \\ anow at: Wolfson Atmospheric Chemistry Laboratories, Department of Chemistry, University of York, YO10 5DD, York, UK \\ ${ }^{b}$ now at: Physikalisches Institut, University of Freiburg, Hermann-Herder Str. 3, 79104 Freiburg, Germany
}

Correspondence: Terry J. Dillon (terry.dillon@york.ac.uk)

Received: 16 June 2017 - Discussion started: 3 July 2017

Revised: 6 October 2017 - Accepted: 18 October 2017 - Published: 21 December 2017

\begin{abstract}
Pulsed laser methods for $\mathrm{OH}$ generation and detection were used to study atmospheric degradation reactions for three important biogenic gases: $\mathrm{OH}+$ isoprene (Reaction R1), $\mathrm{OH}+\alpha$-pinene (Reaction $\mathrm{R} 2$ ) and $\mathrm{OH}+\Delta$ 3-carene (Reaction R3). Gas-phase rate coefficients were characterized by non-Arrhenius kinetics for all three reactions. For $(\mathrm{R} 1), k_{1} \quad(241-356 \mathrm{~K})=(1.93 \pm 0.08) \times$ $10^{-11} \exp \{(466 \pm 12) / T\} \mathrm{cm}^{3}$ molecule ${ }^{-1} \mathrm{~s}^{-1}$ was determined, with a room temperature value of $k_{1}(297 \mathrm{~K})=(9.3 \pm$ $0.4) \times 10^{-11} \mathrm{~cm}^{3}$ molecule ${ }^{-1} \mathrm{~s}^{-1}$, independent of bath-gas pressure (5-200 Torr) and composition ( $\mathrm{M}=\mathrm{N}_{2}$ or air). Accuracy and precision were enhanced by online optical monitoring of isoprene, with absolute concentrations obtained via an absorption cross section, $\sigma_{\text {isoprene }}=(1.28 \pm 0.06) \times$ $10^{-17} \mathrm{~cm}^{2}$ molecule ${ }^{-1}$ at $\lambda=184.95 \mathrm{~nm}$, determined in this work. These results indicate that significant discrepancies between previous absolute and relative-rate determinations of $k_{1}$ result in part from $\sigma$ values used to derive the isoprene concentration in high-precision absolute determinations.

Similar methods were used to determine rate coefficients (in $10^{-11} \mathrm{~cm}^{3}$ molecule ${ }^{-1} \mathrm{~s}^{-1}$ ) for (R2)-(R3): $k_{2}$ (238$357 \mathrm{~K})=(1.83 \pm 0.04) \times \exp \{(330 \pm 6) / T\}$ and $k_{3}(235-$ $357 \mathrm{~K})=(2.48 \pm 0.14) \times \exp \{(357 \pm 17) / T\}$. This is the first temperature-dependent dataset for (R3) and enables the calculation of reliable atmospheric lifetimes with respect to $\mathrm{OH}$ removal for e.g. boreal forest springtime conditions. Room temperature values of $k_{2}(296 \mathrm{~K})=(5.4 \pm$ $0.2) \times 10^{-11} \mathrm{~cm}^{3}$ molecule ${ }^{-1} \mathrm{~s}^{-1}$ and $k_{3}(297 \mathrm{~K})=(8.1 \pm$ $0.3) \times 10^{-11} \mathrm{~cm}^{3}$ molecule ${ }^{-1} \mathrm{~s}^{-1}$ were independent of bathgas pressure (7-200 Torr, $\mathrm{N}_{2}$ or air) and in good agree-
\end{abstract}

ment with previously reported values. In the course of this work, $184.95 \mathrm{~nm}$ absorption cross sections were determined: $\sigma=(1.54 \pm 0.08) \times 10^{-17} \mathrm{~cm}^{2}$ molecule ${ }^{-1}$ for $\alpha$-pinene and $(2.40 \pm 0.12) \times 10^{-17} \mathrm{~cm}^{2}$ molecule ${ }^{-1}$ for $\Delta$-3-carene.

\section{Introduction}

Large quantities and varieties of volatile organic compounds (VOC) are released into Earth's atmosphere from vegetation; such biogenic emissions exceed those of anthropogenic origin by a factor of $\sim 10$ (Goldstein and Galbally, 2007). Isoprene (2-methyl-1,3-butadiene, $\mathrm{C}_{5} \mathrm{H}_{8}$ ) contributes about $40 \%$ (Guenther et al., 1995) of this gigaton $\left(10^{15} \mathrm{~g} \mathrm{C}\right)$ emission of biogenic VOC. The hydroxyl radical, $\mathrm{OH}$, is the primary oxidant in the troposphere, initiating the degradation of most important VOC such as $\mathrm{CH}_{4}$, isoprene and the monoterpenes (two isoprene units; molecular formula of $\mathrm{C}_{10} \mathrm{H}_{16}$ ). (Atkinson and Arey, 2003). VOC lifetimes are thus constrained by $\mathrm{OH}$, and its abundance is an important test of model reliability.

Much attention was recently focussed on chemistry over tropical forests, as these ecosystems influence Earth's chemistry-climate system as the principal sink for the greenhouse gases $\mathrm{CO}_{2}$ and $\mathrm{CH}_{4}$ and source of isoprene and other VOC. Models have traditionally predicted low levels of $\mathrm{OH}$ over tropical forests due to its rapid reactions with VOC (notably isoprene; (R1)) and a lack of efficient $\mathrm{OH}$ regeneration 
mechanisms.

$\mathrm{OH}+$ isoprene $\rightarrow$ (products)

Contrary to these predictions, results from field campaigns have demonstrated that a high $\mathrm{OH}$ concentration is maintained (Butler et al., 2008; Lelieveld et al., 2008; Martinez et al., 2010; Stone et al., 2011), with the greatest discrepancies (factor of $\approx 3$ to 10 ) between measured and modelled [OH] being observed where isoprene mixing ratios were large $(\mathrm{Ku}-$ bistin et al., 2010). The representation of photochemistry in models relies almost exclusively on lab-based measurements e.g. of absorption cross sections, quantum yields, rate coefficients and product yields. For (R1), the rate coefficients $k_{1}(T)$ reported in the literature are characterized by small but significant differences, notably at temperatures away from $298 \mathrm{~K}$. Accordingly, in the work presented in this paper, absolute rate coefficients $k_{1}(241-356 \mathrm{~K})$ were determined by highly accurate methods at realistic atmospheric temperature conditions.

The largest global contribution to atmospheric terpene emissions is from boreal forests covering Canada, northern Europe and Siberia, together encompassing one-third of Earth's forests. Emissions peak in summer due to strong correlations with temperature and photosynthetic activity. However, similar emission maxima have been observed in the autumn and in late winter/early spring when they are attributed to an increase in photorespiration rate (Back et al., 2005; Hakola et al., 2003). Throughout the year shorter bursts of terpene emission, associated with damage induced by e.g. animals (Heijari et al., 2011), pathogens, storms (Haase et al., 2011) and harvesting, may impact on the local $\mathrm{OH}$ budget (Noelscher et al., 2012). Elsewhere, monoterpenes have been detected from other vegetation, notably the forest floor (Hellen et al., 2006) and over active phytoplankton blooms in the Southern Ocean (Yassaa et al., 2008).

Oxidation of terpenes proceeds to a vast number of gasand condensed-phase products, with consequent production of tropospheric ozone, peroxyacyl nitrates and secondary organic aerosol (Atkinson and Arey, 2003). The product distribution from any given monoterpene depends upon physical conditions of temperature, pressure and humidity, together with the identity of the primary oxidant. Reactions with $\mathrm{OH}$, $\mathrm{O}_{3}$ and perhaps $\mathrm{Cl}$ initiate terpene degradation by day, with $\mathrm{NO}_{3}$ contributing at night ( $\mathrm{Ng}$ et al., 2017). The relative importance of these reactions depends on both the availability of the oxidant and the size of the corresponding rate coefficient $k(T)$. These rate coefficients are often reasonably well-established at around ambient temperature, though the database is sparse for terpene reactions for low-temperature conditions $(T<298 \mathrm{~K})$ most relevant to high northern latitudes.

Summertime observations in the Finnish boreal forest (Williams et al., 2011) demonstrate that more than half the total terpene concentration measured above the boreal forest canopy was accounted for by two species: $\alpha$-pinene $(2,6,6-$ trimethylbicyclo-[3.1.1]hept-2-ene) and $\Delta$-3-carene $(3,7,7-$ trimethylbicyclo[4.1.0]hept-3-ene) (Hakola et al., 2012; Yassaa et al., 2008). Accordingly, this paper describes lab-based experiments to study (R2)-(R3) of $\mathrm{OH}$ with these two particularly important biogenic VOC:

$\mathrm{OH}+\alpha$-pinene $\rightarrow$ (products)

$\mathrm{OH}+\Delta$-3-carene $\rightarrow$ (products)

The techniques employed here allowed the first absolute kinetic studies of (R2 and R3) at the temperatures most representative of boreal forests, which can be as low as $253 \mathrm{~K}$ during late-autumn and early-spring months throughout which monoterpene emissions persist (Hakola et al., 2012).

\section{Experimental}

The technique of pulsed laser photolysis (PLP) radical generation coupled to pulsed laser-induced fluorescence (LIF) detection of $\mathrm{OH}$ has been used in several absolute kinetic studies of $\mathrm{OH}+\mathrm{VOC}$ reactions from this laboratory. Details of the apparatus and methods were published previously (Dillon et al., 2012; Karunanandan et al., 2007), and therefore only a brief description is given here.

Experiments were conducted in a $500 \mathrm{~cm}^{3}$ quartz reactor. Cell temperature was controlled by circulating a cryogenic fluid through an outer jacket and monitored with a J-type thermocouple; pressure was monitored using capacitance manometers. Gas flow rates of up to $2000 \mathrm{~cm}^{3} \mathrm{~min}^{-1}$ ensured that a fresh gas sample was available for photolysis at each laser pulse. Fluorescence from $\mathrm{OH}$ was detected by a photomultiplier tube screened by a $309 \mathrm{~nm}$ interference filter and a BG 26 glass cut-off filter. Excitation of the $\mathrm{A}^{2} \Sigma(v=1) \leftarrow \mathrm{X}^{2} \Pi(v=0), Q_{11}(1)$ transition at $282 \mathrm{~nm}$ was achieved using the frequency-doubled emission from a Nd:YAG pumped dye laser. The detection limit at $P=50$ mbar (air) was found to be $\approx 10^{9}$ molecule $\mathrm{cm}^{-3}$ for a $S / N=1$ (20 scans). An exciplex laser operating at $248 \mathrm{~nm}$ $(\mathrm{KrF})$ was used to initiate radical chemistry via photolysis of $\mathrm{H}_{2} \mathrm{O}_{2}$ (Reaction $\mathrm{R} 4$ ).

$\mathrm{H}_{2} \mathrm{O}_{2}+h v(248 \mathrm{~nm}) \rightarrow 2 \mathrm{OH}$

Typically a laser fluence of $12 \mathrm{~mJ} \mathrm{~cm}^{-2}$ was used with $\left[\mathrm{H}_{2} \mathrm{O}_{2}\right]=1 \times 10^{14}$ molecules $\mathrm{cm}^{-3}$ to generate $[\mathrm{OH}] \approx 3 \times$ $10^{11}$ molecules $\mathrm{cm}^{-3}$. Data analysis (see Sect. 3) was considerably simplified by working under pseudo-first-order conditions of $\left[\mathrm{H}_{2} \mathrm{O}_{2}\right] \gg[\mathrm{OH}]$, even when the concentrations of the organic reactant were low, $\mathrm{OH}$ then reacting mainly with $\mathrm{H}_{2} \mathrm{O}_{2}$.

$\mathrm{OH}+\mathrm{H}_{2} \mathrm{O}_{2} \rightarrow \mathrm{HO}_{2}+\mathrm{H}_{2} \mathrm{O}$

Time-dependent $\mathrm{OH}$ profiles were obtained by recording the LIF signal intensity as the delay time between the photolysis 
and the probe lasers was stepped from 0 to a maximum of $15 \mathrm{~ms}$. Accuracy and precision of the rate coefficients determined in this work was further enhanced by online monitoring of the terpenoids isoprene, $\alpha$-pinene and $\Delta-3$-carene by vacuum ultraviolet (VUV) absorption spectroscopy. In order to achieve this, absorption cross sections, $\sigma$, were determined experimentally by recording the attenuation of VUV light by static samples of each terpenoid. Two absorption cells were used with optical path length $l=30.4 \mathrm{~cm}$ (fitted with heated quartz windows) and $l=1 \mathrm{~cm}$. Concentrations were determined by manometric methods, with absolute cell pressure measured to an accuracy of \pm 0.01 Torr using a calibrated 10 Torr capacitance manometer. Samples were supplied either undiluted from the headspace above a liquid sample or from a glass storage bulb as a dilute mixture $(\approx 1$ part in $1000 \mathrm{~N}_{2}$ ). These two supply methods had complementary advantages and disadvantages. Use of undiluted samples was more direct but had uncertainties due to the measurement of small sample pressures and the potential for VOC (present at high concentrations) to condense onto the windows of the $1 \mathrm{~cm}$ absorption cell (high surface area to volume ratio). These problems were minimized when using dilute VOC at higher pressure in the $30 \mathrm{~cm}$ cell (with relatively small surface area to volume ratio) but with the potential for errors associated with sample preparation and storage.

Collimated light from either a low-pressure Hg lamp $(\lambda=184.95 \mathrm{~nm})$ or a $\mathrm{D}_{2}$ lamp $(180-260 \mathrm{~nm})$ transmitted the sample and was focussed onto the entrance slit of a $0.5 \mathrm{~m}$ monochromator equipped with a grating (300 lines $\mathrm{mm}^{-1}$ blazed at $200 \mathrm{~nm}$ ) and a diode array detector. The volume around the lamp, cell and monochromator was purged with $\mathrm{N}_{2}$ to minimize absorption by $\mathrm{O}_{2}, \mathrm{O}_{3}$ or $\mathrm{H}_{2} \mathrm{O}$. Spectra were recorded at an experimental resolution of $0.4 \mathrm{~nm}$, estimated from full width at half maximum observed for either the $\lambda=184.95 \mathrm{~nm}$ or $253.65 \mathrm{~nm} \mathrm{Hg}$ lines, as appropriate. Absorption cross sections were obtained via the Beer-Lambert Law (Eq. 1).

$I=I_{0} \times \exp \{-\sigma l[$ terpenoid $]\}$

where $I$ and $I_{0}$ are respectively the transmitted and incident light intensity and 1 is the optical path length.

Online reagent monitoring in kinetic experiments was conducted downstream from the photolysis cell, using an absorption cell $(l=43.8 \mathrm{~cm})$ equipped with a low-pressure $\mathrm{Hg}$ lamp and a $185 \mathrm{~nm}$ interference filter. This set-up was used to measure absolute reagent concentrations via VUV optical absorption at $\lambda=184.95 \mathrm{~nm}$. Following the application of small corrections for measured $254 \mathrm{~nm}$ stray light intensity $(<8 \%)$ and differences in $T(<30 \%)$ and $P(<1 \%)$ between the cells, [terpenoids] of the order of $10^{12}$ molecule $\mathrm{cm}^{-3}$ could be measured (see Sect. 3.1). A comparison of these optically derived concentrations to approximate manometric measurements was used to confirm that no significant fraction of any of the terpenoids was deposited at the walls in low-temperature experiments.

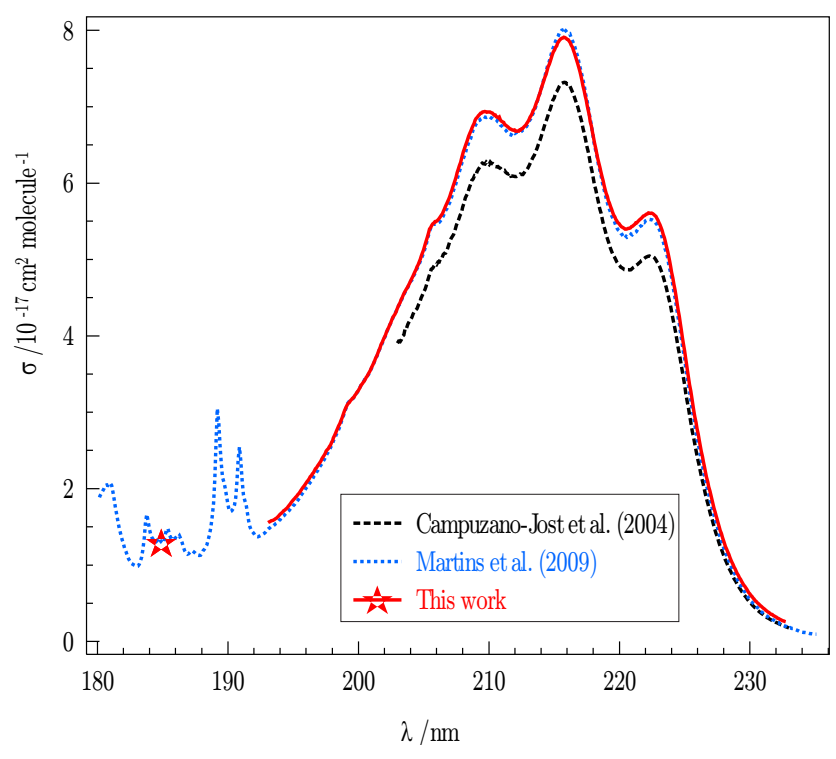

Figure 1. UV absorption spectra for isoprene from this work and from the literature. The red solid line represents data recorded at a resolution of $\pm 0.4 \mathrm{~nm}$; the red star depicts $\sigma_{\text {isoprene }}=(1.28 \pm$ $0.02) \times 10^{-17} \mathrm{~cm}^{2}$ molecule ${ }^{-1}$ at $184.95 \mathrm{~nm}$ (see Fig. 2) subsequently used to derive absolute concentrations for kinetic experiments. Results from this work agree well with the more extensive, high-resolution dataset from Martins et al. (2009) represented here as a blue dotted line.

The chemicals isoprene (Aldrich 99\%, Sigma-Aldrich), $\alpha$-pinene (Aldrich, $98 \%$ ) and $\Delta$-3-carene (Aldrich, 99\%) were degassed by repeated freeze-pump-thaw cycles at $77 \mathrm{~K}$ and diluted in $\mathrm{N}_{2}$ for storage and supply. $\mathrm{H}_{2} \mathrm{O}_{2}$ (Roth, $35 \%$ by weight) was concentrated by pumping away water and introduced to the experiment via a bubbler. $\mathrm{N}_{2}$ and $\mathrm{O}_{2}$ (Messer $99.999 \%$ ) were used without further purification.

\section{Results and discussion}

Detailed below are determinations of absorption cross sections for the terpenoids isoprene, $\alpha$-pinene and $\Delta$-3-carene $(\sigma$, Sect. 3.1) and temperature-dependent rate coefficients for their reactions with $\mathrm{OH}: k_{1}$ in Sect. 3.2 and $k_{2}$ and $k_{3}$ in Sect. 3.3. A discussion of possible systematic uncertainties and a comparison of the results from this work with the existing literature is presented in Sect. 3.4. All other uncertainties quoted throughout are precision only, representing two standard errors.

\subsection{Absorption cross sections ( $\sigma$ ) for isoprene, $\alpha$-pinene and $\Delta-3$-carene}

Figure 1 displays (as the solid red line) the UV absorption spectrum of isoprene obtained in this work, together with results from two earlier studies. Cross sections were obtained at an experimental resolution of $\delta \lambda \approx 0.4 \mathrm{~nm}$ (the full width 
Table 1. UV absorption cross sections for isoprene from this work.

\begin{tabular}{lrrrrrrr}
\hline$\lambda(\mathrm{nm})^{\mathrm{a}}$ & $\sigma^{\mathrm{b}}$ & $\lambda(\mathrm{nm})$ & $\sigma^{\mathrm{b}}$ & $\lambda(\mathrm{nm})$ & $\sigma^{\mathrm{b}}$ & $\lambda(\mathrm{nm})$ & $\sigma^{\mathrm{b}}$ \\
\hline $184.95^{*}$ & 1.28 & 204 & 4.72 & 215 & 7.73 & 226 & 2.75 \\
194 & 1.66 & 205 & 5.13 & 216 & 7.88 & 227 & 1.92 \\
195 & 1.85 & 206 & 5.50 & 217 & 7.44 & 228 & 1.31 \\
196 & 2.07 & 207 & 5.83 & 218 & 6.62 & 229 & 0.90 \\
197 & 2.33 & 208 & 6.38 & 219 & 5.86 & 230 & 0.62 \\
198 & 2.62 & 209 & 6.84 & 220 & 5.46 & 231 & 0.44 \\
199 & 3.04 & 210 & 6.93 & 221 & 5.43 & 232 & 0.32 \\
200 & 3.29 & 211 & 6.81 & 222 & 5.59 & 233 & 0.24 \\
201 & 3.58 & 212 & 6.69 & 223 & 5.50 & 234 & 0.19 \\
202 & 3.99 & 213 & 6.80 & 224 & 4.84 & & \\
203 & 4.36 & 214 & 7.23 & 225 & 3.78 & & \\
\hline
\end{tabular}

a Data obtained at a resolution of $\Delta \lambda \approx 0.4 \mathrm{~nm}$, averaged and reported at $1 \mathrm{~nm}$ intervals except for ${ }^{*} \sigma$ at $184.95 \mathrm{~nm}$ from high-resolution experiment (see Sect. 3.1 and Fig. 2). ${ }^{b} \sigma$ in units of $10^{-17} \mathrm{~cm}^{2}$ molecule -1

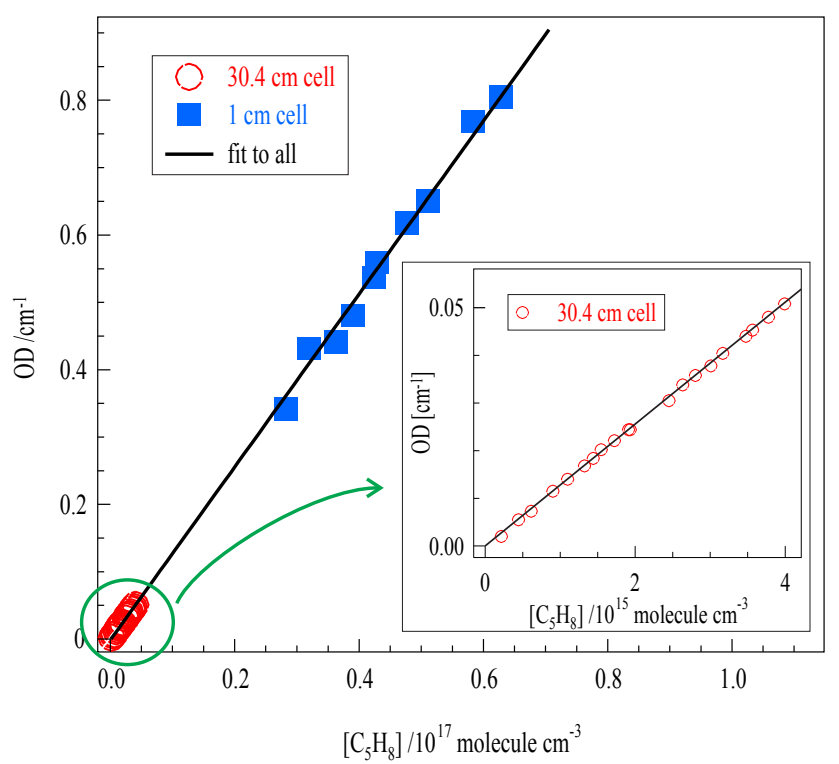

Figure 2. Beer-Lambert plot used to derive the cross section of isoprene at $184.95 \mathrm{~nm}$. An unweighted proportional fit to all the data yields $\sigma_{\text {isoprene }}=(1.28 \pm 0.02) \times 10^{-17} \mathrm{~cm}^{2}$ molecule ${ }^{-1}$, represented by the solid black line on both the main plot and insert. This value (also displayed as the red star in Fig. 1) was subsequently used to calculate isoprene concentrations for kinetic experiments.

half maximum of the $\lambda=253.65 \mathrm{~nm} \mathrm{Hg}$ line) in the range of $194-226 \mathrm{~nm}$ and are reported in Table 1 at $1 \mathrm{~nm}$ intervals. As is evident from Fig. 1, there is excellent agreement ( $\leq 1 \%$ difference) between the results from this work and the more extensive and higher-resolution $(\delta \lambda \approx 0.075 \mathrm{~nm})$ dataset from Martins et al. (2009) depicted by the blue dotted line. Campuzano-Jost et al. (2004) reported cross sections (black dashed line in Fig. 1) in the range of 203-233 nm that are on average about $10 \%$ smaller. The reasons for this discrepancy are unclear, though it seems unlikely to have resulted from problems with sample purity, which was $>99 \%$ in all three studies when supplied. Differences in spectral resolution were also not a likely source of error, since the

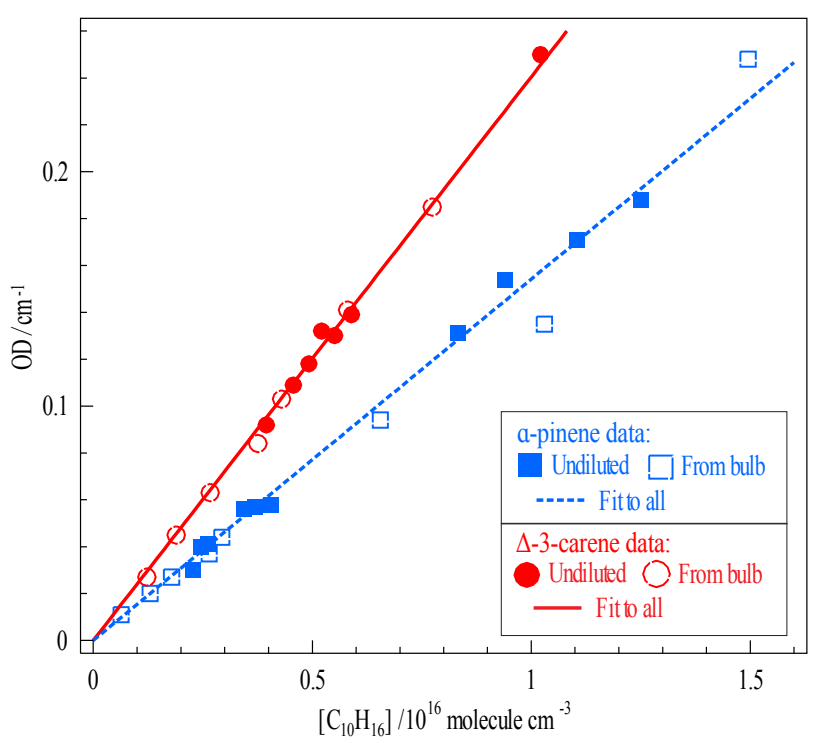

Figure 3. Beer-Lambert plots used to derive $184.95 \mathrm{~nm}$ absorption

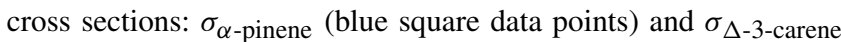
(red circles). Over a wide range of concentrations, good agreement was observed for data from both undiluted samples and from pre-prepared dilute bulbs (Sect. 2). Unweighted proportional fits with (Eq. 1) yield (in units of $10^{-17} \mathrm{~cm}^{2}$ molecule $\left.{ }^{-1}\right) \sigma_{\alpha \text {-pinene }}=$ $(1.54 \pm 0.05)$ and $\sigma_{\Delta-3 \text {-carene }}=(2.40 \pm 0.03)$.

highest-resolution study from Campuzano-Jost et al. (2004) $(\delta \lambda \approx 0.05 \mathrm{~nm})$ reports the smallest differential cross sections.

Also displayed in Fig. 1, the red star depicts results from this work at $\lambda=184.95 \mathrm{~nm}$ that used a low-pressure Hg lamp as light source. Figure 2 displays the corresponding plot of $\ln \left(I_{0} / I\right) / l$ vs. [isoprene], which was used to obtain $\sigma_{\text {isoprene }}$ via Eq. (1). Note the good agreement between data obtained across a wide range of concentrations and over different optical path lengths. A proportional fit to all the data yields a value of $\sigma_{\text {isoprene }}=(1.28 \pm 0.02) \times 10^{-17} \mathrm{~cm}^{2}$ molecule ${ }^{-1}$ at $\lambda=184.95 \mathrm{~nm}$, the wavelength used to derive [isoprene] in subsequent experiments (Sect. 3.2). Evident from Fig. 1 is the good agreement between this discrete value (the red star) and the literature spectrum from Martins et al. (2009), who reported $\sigma_{\text {isoprene }}=1.29 \times 10^{-17} \mathrm{~cm}^{2}$ molecule ${ }^{-1}$. Taking into account potential systematic errors from e.g. manometric measurements and sample purity we estimate an overall uncertainty of $\approx 5 \%$, i.e. $\sigma_{\text {isoprene }}=(1.28 \pm 0.06) \times$ $10^{-17} \mathrm{~cm}^{2}$ molecule ${ }^{-1}$.

Figure 3 displays similar plots of $\ln \left(I_{0} / I\right) / l$ vs. [monoterpene] used to obtain (via Eq. 1) $184.95 \mathrm{~nm}$ absorption cross sections for $\alpha$-pinene and $\Delta$-3-carene. A proportional fit to the $\alpha$-pinene data (blue squares) yields a gradient $\sigma_{\alpha \text {-pinene }}=$ $(1.54 \pm 0.05) \times 10^{-17} \mathrm{~cm}^{2}$ molecule ${ }^{-1}$. Confidence in this result was enhanced by noting that over a wide range of concentrations, good agreement and proportionality were observed for data from both undiluted $\alpha$-pinene samples and 
those supplied dilute from a glass bulb (see Sect. 2). Taking into account potential systematic errors we estimate an overall uncertainty of $\approx 5 \%$, i.e. $\sigma_{\alpha \text {-pinene }}=(1.54 \pm 0.08) \times$ $10^{-17} \mathrm{~cm}^{2}$ molecule ${ }^{-1}$ at $184.95 \mathrm{~nm}$. This value is significantly larger than that listed in the UV spectrum (116$250 \mathrm{~nm}$ ) of Kubala et al. (2009), who report a value of $1.28 \times$ $10^{-17} \mathrm{~cm}^{2}$ molecule ${ }^{-1}$. The reasons for this $\approx 15 \%$ discrepancy are unclear. The Kubala spectrum does display some structure in the region of $175-190 \mathrm{~nm}$, though these features are orders of magnitude coarser than the reported experimental resolution $(\delta \lambda=0.075 \mathrm{~nm})$ or the narrow-bandwidth $(\delta \lambda<0.001 \mathrm{~nm}) \mathrm{Hg}$-line light source used in this work. In the present study, cross sections at $\lambda=184.95 \mathrm{~nm}$ were required to convert online optical measurements into absolute [ $\alpha$-pinene] for rate-coefficient determinations (see Sect. 3.2). As the light source used for $\alpha$-pinene monitoring was also a narrow-bandwidth $\mathrm{Hg}$ lamp, it is appropriate to use the

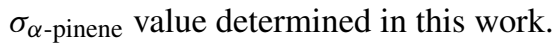

Similar procedures were followed and a similar quality of data obtained (red circles in Fig. 3) in the determination of $\sigma_{\Delta-3 \text {-carene }}=(2.40 \pm 0.03) \times 10^{-17} \mathrm{~cm}^{2}$ molecule ${ }^{-1}$. There appear to be no previously published values for this parameter. It is significantly larger than $\sigma_{\alpha \text {-pinene }}$ and similar to values reported for other terpenes, e.g. $\sigma$ (in $10^{-17} \mathrm{~cm}^{2}$ molecule ${ }^{-1}$ ) $=2.3$ for $\beta$-pinene (Kubala et al., 2009) and 4.6 for limonene (Smialek et al., 2012). Assessment of potential systematic errors results in an overall uncertainty of $\approx 5 \%$, i.e. $\sigma_{\Delta \text {-3-carene }}=(2.40 \pm 0.12) \times$ $10^{-17} \mathrm{~cm}^{2}$ molecule ${ }^{-1}$ at $\lambda=184.95 \mathrm{~nm}$.

\subsection{Absolute determinations of $k_{1}(\mathrm{OH}+$ isoprene $)$}

PLP-LIF studies were carried under pseudo-first-order conditions of [isoprene] $\gg[\mathrm{OH}]$, such that the $\mathrm{OH}$ time profiles, $S(t)$, were described by a simple exponential decay:

$S(t)=S_{0} \exp \{-B t\}$

The parameter $S_{0}$ describes (in arbitrary units) the LIF signal at $t=0$ and is proportional to the initial $[\mathrm{OH}]$ produced by the laser pulse (R4). The parameter $B$ is the pseudofirst-order rate coefficient for $\mathrm{OH}$ decay (and includes components from both reactive and transport losses). Figure 4 displays typical $\mathrm{OH}$ decay profiles recorded in the presence of three different excess [isoprene], whilst other conditions of $P=100$ mbar $\left(\mathrm{N}_{2}\right), T=298 \mathrm{~K}$ and $\left[\mathrm{H}_{2} \mathrm{O}_{2}\right] \approx$ $1 \times 10^{14}$ molecule $\mathrm{cm}^{-3}$ were unchanged. The $\mathrm{OH}$ decays were exponential over at least 2 orders of magnitude and were fit with Eq. (2) to yield values of $B$ with a high degree of precision (two standard errors were generally less than $\pm 2 \%$ ). Systematic errors from unwanted radical chemistry were unlikely, since isoprene absorbs only weakly at the photolysis wavelength $\left(\sigma=1.18 \times 10^{-19} \mathrm{~cm}^{2}\right.$ molecule ${ }^{-1}$ at $248 \mathrm{~nm}$ from Martins et al. 2009), whilst the use of low [OH] ensured that losses of $\mathrm{OH}$ by reaction with itself or with products from (R1) or (R5) could be disregarded in this analysis.

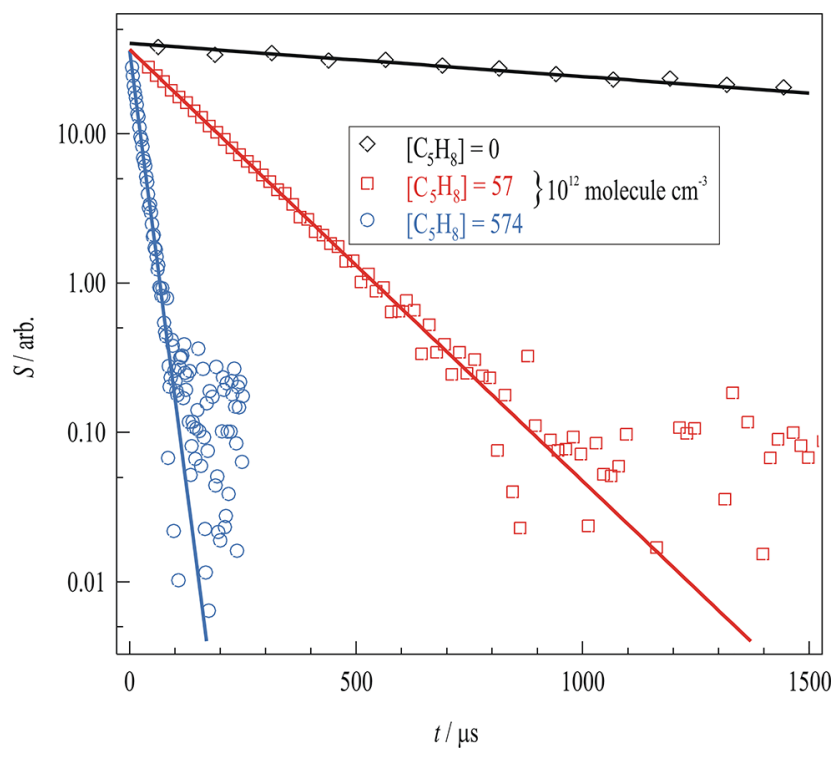

Figure 4. Time-resolved OH LIF signals, $S$, recorded in the presence of different [isoprene] used to determine $k_{1}(298 \mathrm{~K})$. Photolysis Reaction (R5) of $\left[\mathrm{H}_{2} \mathrm{O}_{2}\right]=2.3 \times 10^{14}$ molecule $\mathrm{cm}^{-3}$ was used to generate $[\mathrm{OH}] \approx 5 \times 10^{11}$ molecule $\mathrm{cm}^{-3}$ in $P=103$ Torr $\left(\mathrm{N}_{2}\right)$. Unweighted fits with Eq. (2) yield first-order rate coefficients $B$ for [isoprene] $=0$ (black diamonds) $B=(513 \pm 12) \mathrm{s}^{-1}$ and [isoprene] $=57 \times 10^{12}$ molecule $\mathrm{cm}^{-3}$ (red squares) $B=(6654 \pm$ 44) $\mathrm{s}^{-1}$; [isoprene] $=574 \times 10^{12}$ molecule $\mathrm{cm}^{-3}$ (blue circles) $B=$ $(53473 \pm 700) \mathrm{s}^{-1}$.

Nonetheless, test experiments were conducted using an invariant [isoprene] $=3.2 \times 10^{14}$ molecule $\mathrm{cm}^{-3}$ whilst photolysis laser fluence, and thus radical concentrations, was varied by a factor of 15 . No systematic influence was discerned ( $<1 \%$ variation in $B$ parameters) from such test experiments conducted both in $\mathrm{N}_{2}$ and in air, reinforcing confidence in these results.

Figure 5 displays plots of $B$ vs. [isoprene] at three temperatures, which were fit (Eq. 3) to obtain the bimolecular rate coefficients $k_{1}(T)$.

$B=k_{1}[$ isoprene $]+k_{\text {loss }}$

where $k_{1}$ is the bimolecular rate coefficient of interest. The term $k_{\text {loss }}\left(\mathrm{s}^{-1}\right)$ accounts for other losses of $\mathrm{OH}$, here dominated by (R5) with the photolysis precursor $\mathrm{H}_{2} \mathrm{O}_{2}$, with some small contribution from diffusion and flow out of the reaction zone.

The data display good linearity, with the slopes identified as $k_{1}(T)$ at three different temperatures and intercept values (around $B=200 \mathrm{~s}^{-1}$ ) in line with the predicted loss rate for reaction with $\mathrm{H}_{2} \mathrm{O}_{2}(\mathrm{R} 5)$. A mean of six values obtained at room temperature yields $k_{1}(297 \mathrm{~K})=(9.3 \pm 0.2) \times$ $10^{-11} \mathrm{~cm}^{3}$ molecule $\mathrm{s}^{-1}$. Within the experimental uncertainty, the measured rate coefficients were found to be independent of the bath-gas pressure $(3.8<P /$ Torr $<165)$ or identity $\left(\mathrm{N}_{2}\right.$ or air). Experimental conditions and results of 


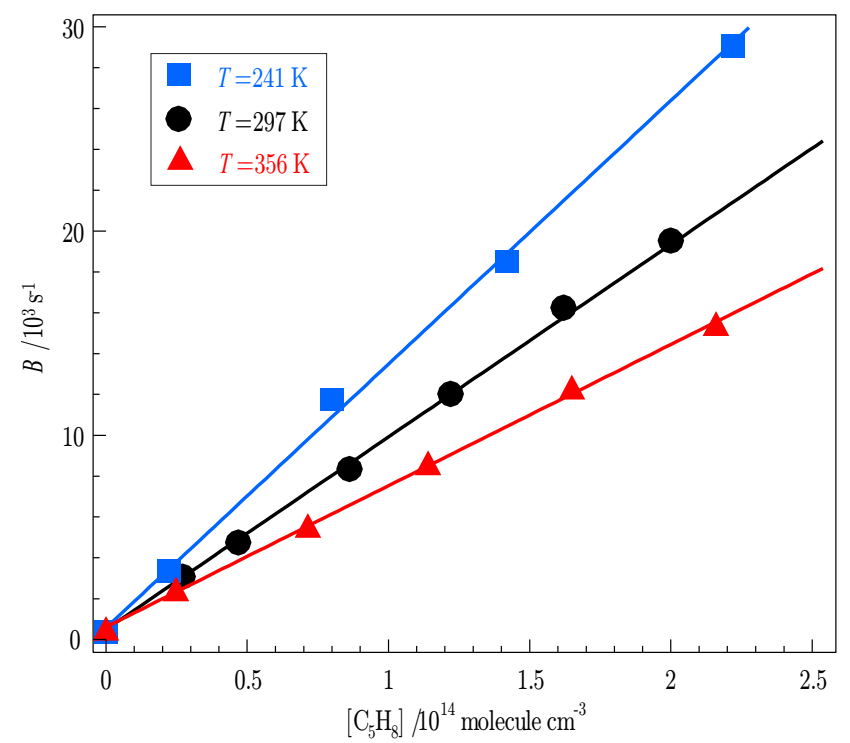

Figure 5. Plots of $B$ parameters vs. associated [isoprene] used to determine $k_{1}$ at three different temperatures. Weighted linear fits (Eq. 3) to the data yield (in units of $10^{-11} \mathrm{~cm}^{3}$ molecule ${ }^{-1} \mathrm{~s}^{-1}$ ): $k_{1}(241 \mathrm{~K})=(12.9 \pm 0.2)$ from the blue square data points; $k_{1}$ $(297 \mathrm{~K})=(9.43 \pm 0.14)$ from the black circles and $k_{1}(356 \mathrm{~K})=$ $(6.92 \pm 0.13)$ from the red triangles. Note that error bars on individual data points are too small to be seen here (typically a few hundred on decay rates of several thousand per second).

all such determinations of $k_{1}$ are listed in Table 2. Note that the optical derivation of [isoprene] at $184.95 \mathrm{~nm}$ means that ratios of $k_{1} / \sigma_{\text {isoprene }}$ were actually determined and that any subsequent improvements in the database for isoprene cross sections may be used to update the kinetic results from this work. Taking into account potential systematic errors, principally from $\sigma_{\text {isoprene, }}$, and a small (2 to $4 \%$ ) uncertainty in carrying out the optical measurements, we estimate a realistic overall error of $\pm 5 \%$ or $k_{1}(297 \mathrm{~K})=(9.3 \pm 0.4) \times$ $10^{-11} \mathrm{~cm}^{3}$ molecule $\mathrm{e}^{-1} \mathrm{~s}^{-1}$

The data displayed in Fig. 5 further reveal the "negative" or non-Arrhenius temperature dependence for $k_{1}$, with the largest slopes obtained in experiments conducted at the lowest temperatures $(241 \mathrm{~K})$. This trend for $k_{1}(T)$ is wellestablished in the literature; results from these previous studies, together the $k_{1}$ values from this work (listed in Table 2), are depicted in Fig. 6.

\subsubsection{Comparison of $k_{1}$ with literature values}

The kinetic database for (R1) displays some inconsistencies, with results for $k_{1}(298 \mathrm{~K})$ from a recent absolute determination by Campuzano-Jost et al. (2004) some $15 \%$ smaller than other values reported, mostly from relative-rate studies (Atkinson et al., 2006b). The ambient temperature results from this work lie in between these two extremes. Absolute determinations of $k_{1}$ were generally conducted at lower pres-
Table 2. Summary of rate coefficients $k_{1}, k_{2}$ and $k_{3}$ determined in this work.

\begin{tabular}{|c|c|c|c|c|}
\hline$T / K$ & $P /$ Torr $^{\mathrm{a}}$ & ${\text { [terpene }]^{b}}^{b}$ & $n^{\mathrm{c}}$ & $k / 10^{-11 \mathrm{~d}}$ \\
\hline \multicolumn{5}{|c|}{$\mathrm{OH}+$ isoprene $\rightarrow$ (products) $(\mathrm{R} 1)$} \\
\hline 241 & 6.0 & $22-222$ & 5 & $12.9 \pm 0.2$ \\
\hline 241 & $6.1^{*}$ & $22-222$ & 5 & $13.2 \pm 0.3$ \\
\hline 268 & 6.7 & $21-187$ & 6 & $11.3 \pm 0.14$ \\
\hline 298 & 3.8 & $39-287$ & 5 & $9.20 \pm 0.06$ \\
\hline 297 & 7.5 & $27-200$ & 6 & $9.43 \pm 0.14$ \\
\hline 298 & 42.9 & $72-438$ & 8 & $9.19 \pm 0.05$ \\
\hline 298 & 71.0 & $29-223$ & 7 & $9.12 \pm 0.10$ \\
\hline 298 & 103 & $57-574$ & 7 & $9.20 \pm 0.05$ \\
\hline 298 & $103^{*}$ & $112-574$ & 5 & $9.22 \pm 0.09$ \\
\hline 296 & 165 & $19-168$ & 7 & $9.1 \pm 0.4$ \\
\hline 296 & $165^{*}$ & $19-168$ & 7 & $9.2 \pm 0.4$ \\
\hline 330 & 8.1 & $15-236$ & 6 & $7.91 \pm 0.12$ \\
\hline 356 & 9.0 & $25-216$ & 6 & $6.92 \pm 0.13$ \\
\hline \multicolumn{5}{|c|}{$\mathrm{OH}+\alpha$-pinene $\rightarrow$ (products) $(\mathrm{R} 2)$} \\
\hline 238 & 6.0 & $7-90$ & 7 & $7.33 \pm 0.04$ \\
\hline 241 & 211 & $47-357$ & 6 & $7.5 \pm 0.2$ \\
\hline 246 & $96^{*}$ & $13-554$ & 4 & $7.23 \pm 0.10$ \\
\hline 246 & 97 & $131-554$ & 4 & $6.94 \pm 0.05$ \\
\hline 256 & 6.5 & $18-84$ & 6 & $6.76 \pm 0.07$ \\
\hline 274 & 7.0 & $8-30$ & 5 & $6.12 \pm 0.14$ \\
\hline 296 & 7.5 & $5-65$ & 7 & $5.50 \pm 0.08$ \\
\hline 296 & 96 & $43-464$ & 5 & $5.38 \pm 0.06$ \\
\hline 296 & $97^{*}$ & $43-464$ & 5 & $5.25 \pm 0.09$ \\
\hline 296 & 197 & $38-420$ & 6 & $5.39 \pm 0.04$ \\
\hline 323 & 7.2 & $19-157$ & 7 & $5.44 \pm 0.08$ \\
\hline 357 & 6.9 & $24-240$ & 7 & $4.82 \pm 0.05$ \\
\hline \multicolumn{5}{|c|}{$\mathrm{OH}+\Delta$-3-carene $\rightarrow$ (products) $(\mathrm{R} 3)$} \\
\hline 235 & 7.5 & $4-43$ & o & $11.9 \pm 0.3$ \\
\hline 241 & 211 & 13-99 & 6 & $11.4 \pm 0.3$ \\
\hline 271 & 96 & $44-530$ & 5 & $9.11 \pm 0.13$ \\
\hline 296 & 95 & $42-377$ & 8 & $8.01 \pm 0.13$ \\
\hline 296 & $95^{*}$ & $42-377$ & 8 & $8.08 \pm 0.13$ \\
\hline 298 & 7.4 & $8-63$ & 7 & $8.10 \pm 0.10$ \\
\hline 298 & 48 & 9-90 & 8 & $8.27 \pm 0.08$ \\
\hline 298 & 205 & $34-262$ & 9 & $8.1 \pm 0.2$ \\
\hline 323 & 7.1 & $8-66$ & 6 & $7.9 \pm 0.2$ \\
\hline 357 & 6.9 & 10-99 & 7 & $6.92 \pm 0.12$ \\
\hline
\end{tabular}

a Bath-gas identity $\mathrm{M}$ is $\mathrm{N}_{2}$ unless marked ${ }^{*}$, where $\mathrm{M}$ is air. ${ }^{\mathrm{b}}$ Units of [terpene] are $10^{12}$ molecules $\mathrm{cm}^{-3}$, with values derived from optical measurements using $185 \mathrm{~nm} \sigma$ values determined in this work. ${ }^{\mathrm{c}} n=$ number of different [terpene] used in determination of $k .{ }^{\mathrm{d}}$ Units of $k$ are $10^{-11} \mathrm{~cm}^{3}$ molecule ${ }^{-1} \mathrm{~s}^{1}$; uncertainties quoted are statistical only (two standard errors) derived from weighted linear fits (see Figs. 5 and 8)

sure than the majority of the relative-rate studies and could therefore yield values that underestimate $k_{1}(1 \mathrm{bar}, 298 \mathrm{~K})$ if the reaction was not at the high-pressure limit under all experimental conditions. However, results from this work revealed no systematic change in $k_{1}$ over the range pressure from 3.8 to 165 Torr, in good qualitative agreement with the 


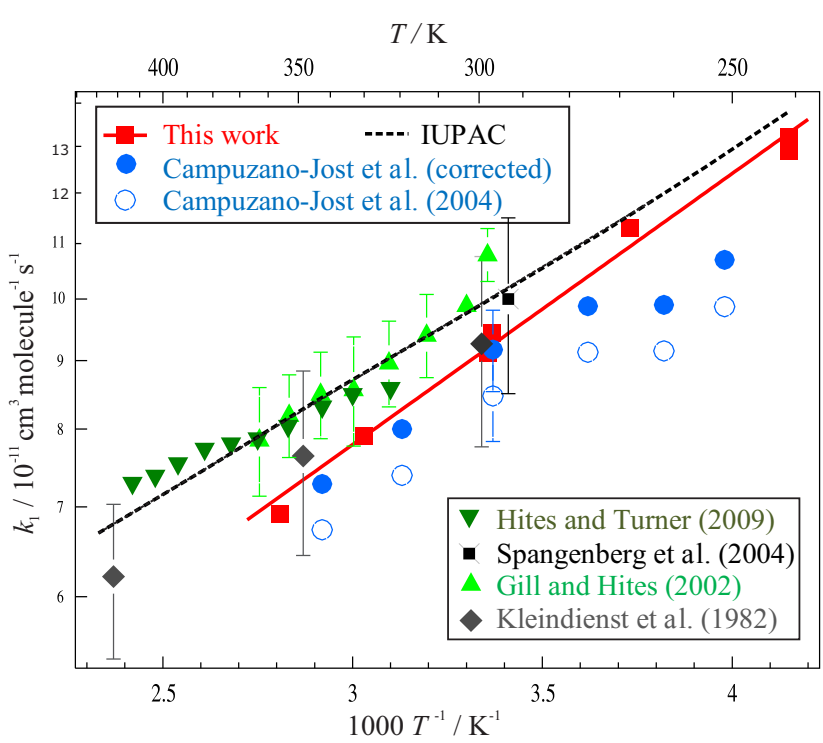

Figure 6. Values of $k_{1}(T)$ from this work and the literature. A fit of Eq. (4) to our data (red squares) yields $k_{1}(241-356 \mathrm{~K})=$ $(1.93 \pm 0.08) \times 10^{-11} \exp \{(466 \pm 12) / T\} \mathrm{cm}^{3}$ molecule ${ }^{-1} \mathrm{~s}^{-1}$, independent of bath-gas pressure and identity $\left(\mathrm{N}_{2}\right.$ or air). Also displayed are the data from Campuzano-Jost et al. (2004) presented as published (open blue circles) and subsequently corrected using isoprene absorption cross sections from Martins et al. (2009) (solid blue circles; see Sect. 3.2.1 for details). Note that error bars were included for all datasets but were commonly smaller than the data markers. The dashed black line represents the current IUPAC recommendation of $k_{1}(240-430 \mathrm{~K})=2.7 \times$ $10^{-11} \exp (390 / T) \mathrm{cm}^{3}$ molecule $\mathrm{s}^{-1} \mathrm{~s}^{-1}$. Not displayed for reasons of clarity are the $T<220 \mathrm{~K}$ data points from Spangenberg et al. (2004), results from low-pressure studies of Park et al. (2004) or the many literature results at around $T=298 \mathrm{~K}$ only (see IUPAC).

results from Campuzano-Jost et al. (2004) (50 to 600 Torr, $\mathrm{N}_{2}$ or air). Results from two studies of $k_{1}(298 \mathrm{~K})$ conducted at lower pressures indicate that the high-pressure limit was close to 3 Torr (He) (Singh and $\mathrm{Li}, 2007$ ) and 1 Torr (He) (Chuong and Stevens, 2000). In contrast, McGivern et al. (2000) and Park et al. (2004) observed fall-off behaviour for $k_{1}(298 \mathrm{~K})$ over the pressure range $0.5<P(\mathrm{Ar}) /$ Torr $<20$, in line with their CVTST/RRKM calculations. Whilst no low-pressure studies of $k_{1}(P)$ using $\mathrm{N}_{2}$ or air bath gas are available, the consensus would appear to be that the $k_{1}$ $(298 \mathrm{~K})$ values reported in this work at up to $P=165$ Torr $\left(\mathrm{N}_{2}\right)$ and by (Campuzano-Jost et al., 2004) are close to the high-pressure limit, representative of $k_{1}$ (760 Torr) and thus directly comparable to the relative-rate results in the literature.

The experimental methods used in this work were similar to those employed by Campuzano-Jost et al. (2004), who obtained $k_{1} \quad(297 \mathrm{~K})=(8.47 \pm 0.59) \times$ $10^{-11} \mathrm{~cm}^{3}$ molecule $\mathrm{s}^{-1} \mathrm{~s}^{-1}$, lower than most other determinations and at the lower limit of the range quoted in the IUPAC (Task Group on Atmospheric Chemical Kinetic Data Evaluation) recommendation. Campuzano-Jost et al. (2004) used a cross section of $8.29 \times 10^{-18} \mathrm{~cm}^{2}$ molecule ${ }^{-1}$ at $228.8 \mathrm{~nm}$ when determining [isoprene] from optical measurements. The extensive high-resolution dataset from Martins et al. (2009) provides cross sections at both 228.8 and at $184.95 \mathrm{~nm}$ (used in this work). If cross sections from Martins et al. (2009) are used to derive [isoprene] for the Campuzano-Jost et al. (2004) results, a value of $k_{1} \quad(297 \mathrm{~K})=(9.2 \pm 0.7) \times 10^{-11} \mathrm{~cm}^{3}$ molecule ${ }^{-1} \mathrm{~s}^{-1}$ is obtained (see also the filled blue circle data points in Fig. 6), consistent with results from this work. A similar re-evaluation using cross sections from Martins et al. (2009) does not change the rate coefficients from our study.

Evaluation of all ambient temperature literature to date led IUPAC to recommend a room temperature rate coefficient of $k_{1}(298 \mathrm{~K})=1.0 \times 10^{-10} \mathrm{~cm}^{3}$ molecule $\mathrm{s}^{-1} \mathrm{~s}^{-1}$, slightly larger than the upper limit to our determination, though the two values overlap given that IUPAC quotes an uncertainty of $\Delta \log \left(k_{1}\right)=0.06$ (i.e. in $10^{-11} \mathrm{~cm}^{3}$ molecule ${ }^{-1} \mathrm{~s}^{-1}$ ): $8.71<k_{1}(298 \mathrm{~K})<10.15$. The results obtained in this work, together with the re-calculation of the results from Campuzano-Jost et al. (2004), could indicate that this evaluation is quoted with an overly conservative uncertainty.

The results from previous studies of $k_{1}(T)$ together with the IUPAC recommendation and the data from this work (red squares) are presented in Arrhenius format in Fig. 6. All temperature-dependent investigations characterized $k_{1}(T)$ with a non-Arrhenius temperature dependence, in qualitative agreement with results from this work. However, there are surprisingly few published studies of (R1) over a range of temperatures characteristic of the troposphere, with only Campuzano-Jost et al. (2004) and Park et al. (2004) reporting values of $k_{1}(T<298 \mathrm{~K})$. As is evident from Fig. 6, the spread of $k_{1}(T<298 \mathrm{~K})$ is large, around $\pm 30 \%$ from the uncorrected values from Campuzano-Jost et al. (2004) to the results from Park et al. (2004) at $T=279 \mathrm{~K}$. IUPAC have completed an extensive evaluation of this literature, together with $k_{1}(249-438 \mathrm{~K})$ results from Siese et al. (1994) and many published values at $T \approx 298 \mathrm{~K}$ (not displayed in Fig. 6 for reasons of clarity). The Arrhenius Eq. (4) was used to parameterize $k_{1}$ :

$k_{1}(T)=A \exp \left\{\frac{E}{R T}\right\}$

with recommended parameters of $k_{1}(240-430 \mathrm{~K})=2.7 \times$ $10^{-11} \exp \{390 / T\} \mathrm{cm}^{3}$ molecule ${ }^{-1} \mathrm{~s}^{-1}$, with associated uncertainties of $\Delta \log k_{1}$ of \pm 0.06 at $298 \mathrm{~K}$ and $\Delta \frac{E}{R}$ of $\pm 100 \mathrm{~K}$ to account for the scarcity and spread of $k_{1}(T)$ data. A weighted fit of Eq. (4) to the data from this work yields $k_{1}(241-356 \mathrm{~K})=(1.93 \pm 0.08) \times 10^{-11} \exp \{(466 \pm$ 12) $/ T\} \mathrm{cm}^{3}$ molecule $\mathrm{e}^{-1} \mathrm{~s}^{-1}$, an adequate parameterization over this limited range of temperature. The good agreement between the experimental results obtained in this work, the corrected values from Campuzano-Jost et al. (2004) 


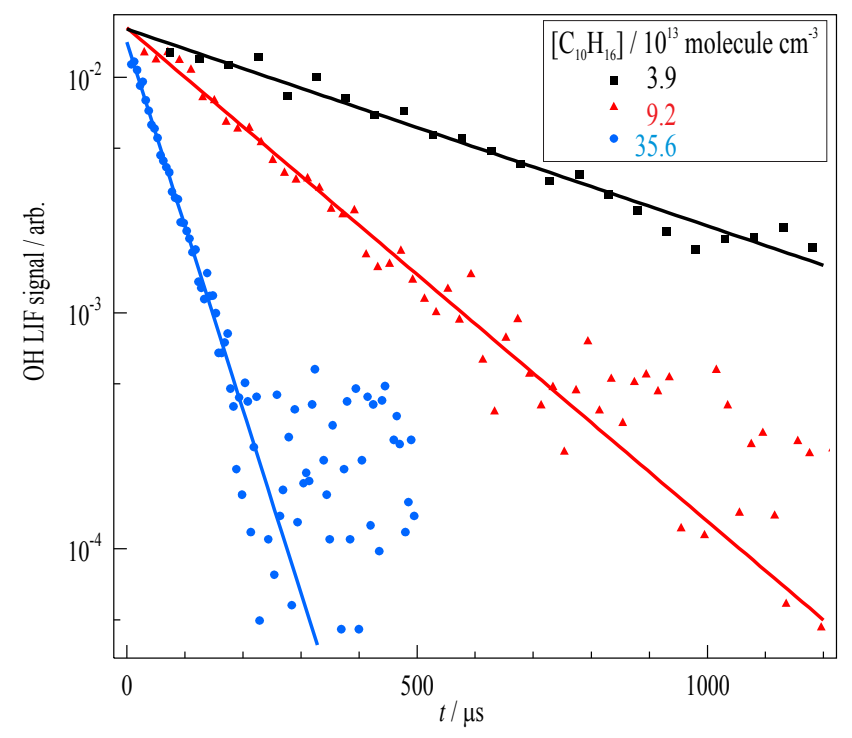

Figure 7. Plot of typical LIF profiles recorded for three $\alpha$-pinene concentrations, used to determine $k_{2}$ (296 K). For all experiments photolysis (R4) at $t=0$ generated [OH] $\approx 5 \times 10^{11}$ molecule $\mathrm{cm}^{-3}$ in $P=97$ Torr (air). Unweighted fits with (Eq. 2) yield $B$ parameters for $[\alpha$-pinene] $=3.9 \times$ $10^{13}$ molecule $\mathrm{cm}^{-3}$ (black squares), $B=(1921 \pm 90) \mathrm{s}^{-1} ; \quad[\alpha-$ pinene $]=9.2 \times 10^{13}$ molecule $\mathrm{cm}^{-3}$ (red triangles), $B=(4819 \pm$ 213) $\mathrm{s}^{-1}$ and $[\alpha$-pinene $]=35.6 \times 10^{13}$ molecule $\mathrm{cm}^{-3}$ (blue circles $), B=(17944 \pm 615) \mathrm{s}^{-1}$.

and the IUPAC recommendation would indicate that the recommended uncertainties could be reduced in any subsequent re-evaluation by IUPAC. Results from Spangenberg et al. (2004), with $k_{1}(58-300 \mathrm{~K})$ reaching a maximum value of $\sim 3 \times 10^{-10} \mathrm{~cm}^{3}$ molecule ${ }^{-1} \mathrm{~s}^{-1}$ at around $T=120 \mathrm{~K}$, demonstrate that large errors could result if the Arrhenius expressions presented here and by IUPAC were extrapolated beyond the temperature range stated.

\subsection{Absolute determinations of $k_{2}$ and $k_{3}$}

Figure 7 displays OH LIF profiles recorded in the presence of three different excess $\alpha$-pinene concentrations, with conditions of $P=97$ Torr (air), $T=296 \mathrm{~K}$ and $\left[\mathrm{H}_{2} \mathrm{O}_{2}\right] \approx$ $1 \times 10^{14}$ molecule $\mathrm{cm}^{-3}$ otherwise unchanged. The $\mathrm{OH}$ decays were exponential over approximately 2 orders of magnitude and were therefore fit with Eq. (2) to yield $B$ parameters with a high degree of precision ( $\pm 5 \%$ or less). As with the determinations of $k_{1}$ detailed above, systematic errors due to secondary chemistry were considered unlikely, since monoterpenes absorb only weakly at the photolysis wavelength (the $248 \mathrm{~nm}$ cross section is $<1 \times$ $10^{-20} \mathrm{~cm}^{2}$ molecule ${ }^{-1}$ (Kubala et al., 2009), resulting in photolysis of $<1 \times 10^{11}$ molecule $\mathrm{cm}^{-3}$ ) of $\alpha$-pinene. Furthermore, use of small $\mathrm{OH}$ concentrations and hence low conversion of $\alpha$-pinene ensured that perturbations to the LIF profiles by reaction of $\mathrm{OH}$ with itself or with the products of

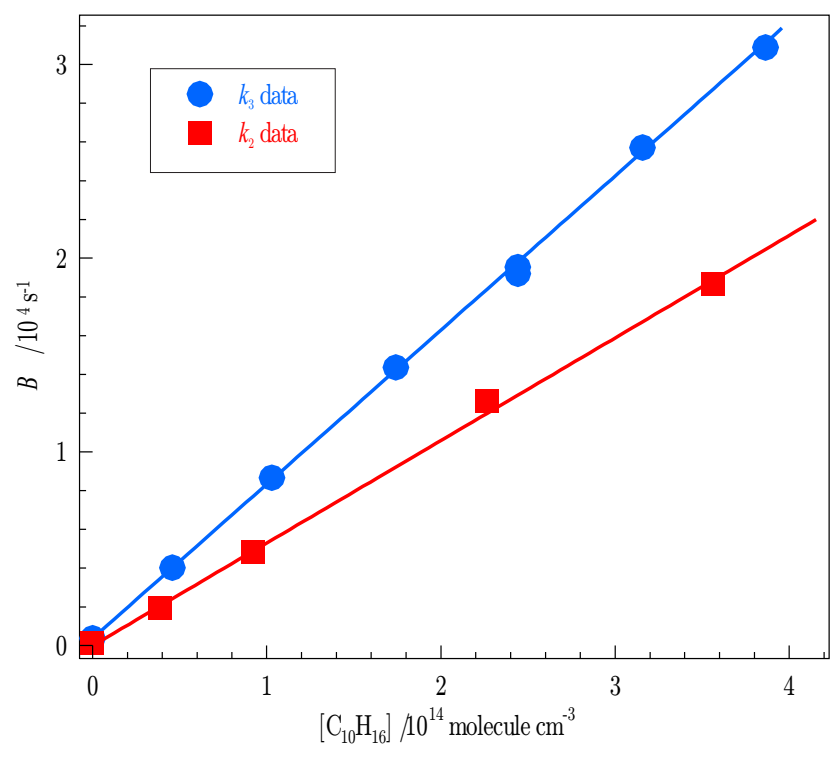

Figure 8. Plots of $B$ parameters derived from Eq. (2) vs. associated $\left[\alpha\right.$-pinene] used to determine $k_{2}(\mathrm{OH}+\alpha$-pinene $)$ and $k_{3}(\mathrm{OH}$ $+\Delta$-3-carene) in conditions of $T=296 \mathrm{~K}$ and $P=97$ Torr (air). Weighted linear fits yield (in units of $10^{-11} \mathrm{~cm}^{3}$ molecule ${ }^{-1} \mathrm{~s}^{-1}$ ): $k_{2}(296 \mathrm{~K})=(5.3 \pm 0.15)$ from the red squares and $k_{3}(296 \mathrm{~K})=$ $(8.1 \pm 0.1)$ (blue circles). Note that $2 \sigma$ statistical errors in $B$, used to weight these fits, were smaller than the symbols in this plot.

(R2) or (R5) could be disregarded in this analysis. All data for (R2) and (R3) recorded in this work were of similar or superior quality to that presented in Fig. 7, where the presence of the efficient fluorescence quencher $\mathrm{O}_{2}$ and relatively large bath-gas pressures had a negative impact on LIF signal quality.

The red squares in Fig. 8 represent results from a series of experiments conducted at $P=97$ Torr (air) and $T=296 \mathrm{~K}$. Values of $B$ were plotted against [ $\alpha$-pinene] calculated from its optical extinction at $184.95 \mathrm{~nm}$ (see Sect. 2). A weighted linear fit (using statistical errors in $B$ ) yields a gradient of $k_{2}$ $(296 \mathrm{~K})=(5.3 \pm 0.2) \times 10^{-11} \mathrm{~cm}^{3}$ molecule ${ }^{-1} \mathrm{~s}^{-1}$. The experimental conditions used and results obtained for all determinations of $k_{2}$ are listed in Table 1. A mean of the four values obtained at around room temperature yields $k_{2}(296 \mathrm{~K})=$ $(5.4 \pm 0.2) \times 10^{-11} \mathrm{~cm}^{3}$ molecule ${ }^{-1} \mathrm{~s}^{-1}$. Within experimental uncertainty, these rate coefficients were independent of the bath-gas pressure $(7<P /$ Torr $<197)$ or identity $\left(\mathrm{N}_{2}\right.$ or air). This result is in reasonable agreement with a number of experimental and theoretical determinations of $k_{1}$ at around ambient temperature, summarized in Table 3.

Experiments conducted at various temperatures revealed a "negative" or non-Arrhenius temperature dependence for $k_{2}$, with the largest values obtained in experiments conducted at the lowest temperatures. This trend for $k_{2}(T)$ is wellestablished by four literature datasets (Chuong and Stevens, 2000; Gill and Hites, 2002; Kleindienst et al., 1982; Montenegro et al., 2012) and is commonly observed for other rad- 
Table 3. Comparison with literature determinations of $k_{2}$ and $k_{3}$ at around $298 \mathrm{~K}$.

\begin{tabular}{|c|c|c|c|}
\hline$k^{\mathrm{a}}$ & $T / K$ & Reference & Techniques used ${ }^{\mathrm{b}}$ \\
\hline \multicolumn{4}{|c|}{ Absolute determinations of $k_{2}(\mathrm{OH}+\alpha$-pinene $)$} \\
\hline $5.4 \pm 0.2^{\mathrm{c}}$ & 296 & This work & PLP-LIF \\
\hline $6.09 \pm 0.3$ & 300 & Davis and Stevens (2005) & DF-LIF \\
\hline $6.08 \pm 0.4$ & 300 & Chuong et al. (2002) & DF-LIF \\
\hline $6.01 \pm 0.82$ & 298 & Kleindienst et al. (1982) & FP-RF \\
\hline \multicolumn{4}{|c|}{ Relative-rate determinations of $k_{2}$} \\
\hline $5.33 \pm 0.79$ & 298 & Dash et al. (2014) & GC vs. propene \\
\hline $5.38 \pm 0.3$ & 298 & Renbaurn-Wolff and Smith (2012) & MS vs. isoprene \\
\hline $5.55 \pm 0.97$ & 298 & Montenegro et al. (2012) & DF-MS vs. isoprene \\
\hline $5.0 \pm 1.1$ & 298 & Gill and Hites (2002) & $\begin{array}{l}\text { MS vs. 1-butene, 2-methylpropene } \\
\text { and trans-2-butene }\end{array}$ \\
\hline $5.35 \pm 0.31$ & $294 \pm 1$ & Atkinson et al. (1986) & GC vs. 2,3-dimethyl-2-butene \\
\hline $5.8 \pm 1.7^{\mathrm{d}}$ & 305 & Winer et al. (1976) & GC vs. 2-methylpropene \\
\hline \multicolumn{4}{|c|}{ Rate theory for $k_{2}$} \\
\hline 4.65 & 298 & Dash et al. (2014) & CVTST \\
\hline 5.1 & 298 & Vereecken et al. (2007) & Estimate using SAR \\
\hline 5.1 & 300 & Fan et al. (2005) & CVTST \\
\hline 12 & 298 & Grosjean and Williams (1992) & Estimate using SAR \\
\hline \multicolumn{4}{|c|}{ Absolute determinations of $k_{3}(\mathrm{OH}+\Delta$-3-carene $)$} \\
\hline $8.1 \pm 0.3^{c}$ & $297 \pm 1$ & This work & PLP-LIF \\
\hline \multicolumn{4}{|c|}{ Relative-rate determinations of $k_{3}$} \\
\hline $8.7 \pm 0.4$ & $294 \pm 1$ & Atkinson et al. (1986) & GC vs. 2,3-dimethyl-2-butene \\
\hline \multicolumn{4}{|c|}{ Rate theory for $k_{3}$} \\
\hline 0.506 & 298 & Baptista et al. (2014) & QM calculations \\
\hline 8.51 & 298 & Peeters et al. (2007) & Estimate using SAR \\
\hline 9.1 & 298 & Grosjean and Williams (1992) & Estimate using SAR \\
\hline $\begin{array}{l}\text { Units of } k_{1} \text { are } 1 \\
\text { lorescence, FP is } \\
\text { S is mass spectr } \\
\text { Calculated using } \\
\text { d kinetic proced } \\
\text { Immann et al., } 2\end{array}$ & $\begin{array}{l}-11 \mathrm{~cm}^{3} \mathrm{~mol} \\
\text { conventional } \\
\text { netry, CVTS } \\
\text { values from } \\
\text { re; see Sect. } 3 \\
16 \text {; Atkinson }\end{array}$ & $\begin{array}{l}\text { cule }{ }^{-1} \mathrm{~s}^{1} \cdot \mathrm{b} \text { Key to abbreviations: PLP is puls } \\
\text { lash photolysis, RF is resonance fluorescence, } \\
T \text { is canonical variational transition state theory, } \\
\text { this work. Realistic uncertainty estimate is } \pm 8 \\
\text { 3). }{ }^{\mathrm{d}} \text { Recalculated using latest } k(298 \mathrm{~K})=5.1 \\
\text { tal., 2006a) for reference reaction } \mathrm{OH}+\text { isobut }\end{array}$ & $\begin{array}{l}\text { daser photolysis, LIF is laser-induced } \\
\text { F is discharge flow, GC is gas chromatography, } \\
\text { ind SAR is structure activity relationship. } \\
\text { for } k_{1} \text { and } k_{2} \text { (includes systematic errors in } \sigma \\
10^{-11} \mathrm{~cm}^{3} \text { molecule } \mathrm{s}^{-1} \text { from IUPAC } \\
\text { ne. }\end{array}$ \\
\hline
\end{tabular}

ical additions to alkenes. Results from these previous studies, together with the $k_{2}$ values from this work (themselves listed in Table 2), are summarized in Table 3 and depicted in Fig. 9.

A similar methodology was followed to determine $k_{3}(T)$ for the reaction of $\mathrm{OH}+\Delta-3$-carene. LIF profiles (not shown) were of a similar quality to those depicted in Fig. 7 and were fit Eq. (2) to obtain $B$ parameters. Optical signals were converted Eq. (1) to absolute [ $\Delta$-3-carene] using values of $l=43.8 \mathrm{~cm}$ and $\sigma_{\Delta-3 \text {-carene }}=2.4 \times 10^{-17} \mathrm{~cm}^{2}$ molecule ${ }^{-1}$ as determined in this work (Sect. 3.1). Figure 8 displays (blue circles) a plot of $B$ vs. [ $\Delta$-3-carene] for a series of experiments conducted at $T=296 \mathrm{~K}$ and $P=96$ Torr (air). The rate coefficient for (R3) is clearly larger than that determined for (R2) above; a weighted linear fit yields a gradient $k_{3}(296 \mathrm{~K})=(8.1 \pm 0.1) \times 10^{-11} \mathrm{~cm}^{3}$ molecule ${ }^{-1} \mathrm{~s}^{-1}$. Exper- iments were repeated using different bath-gas pressures and in $\mathrm{N}_{2}$ (see Table 2). No trends in $k_{3}$ were observed and a mean of these five results yields $k_{3}(297 \pm 1)=(8.1 \pm 0.2) \times$ $10^{-11} \mathrm{~cm}^{3}$ molecule ${ }^{-1} \mathrm{~s}^{-1}$. Results from all experiments, depicted as black circles in Fig. 9, demonstrate for the first time the non-Arrhenius temperature dependence for $k_{3}(T)$.

\subsubsection{Comparison of $k_{2}$ and $k_{3}$ with literature values}

Table 3 presents a comparison of the ambient temperature values of $k_{2}$ and $k_{3}$ determined in this work with the available literature. Regarding $k_{2}$, there is excellent agreement between the results of this work and those obtained by the relative-rate technique (Atkinson et al., 1986; Gill and Hites, 2002; Montenegro et al., 2012; Winer et al., 


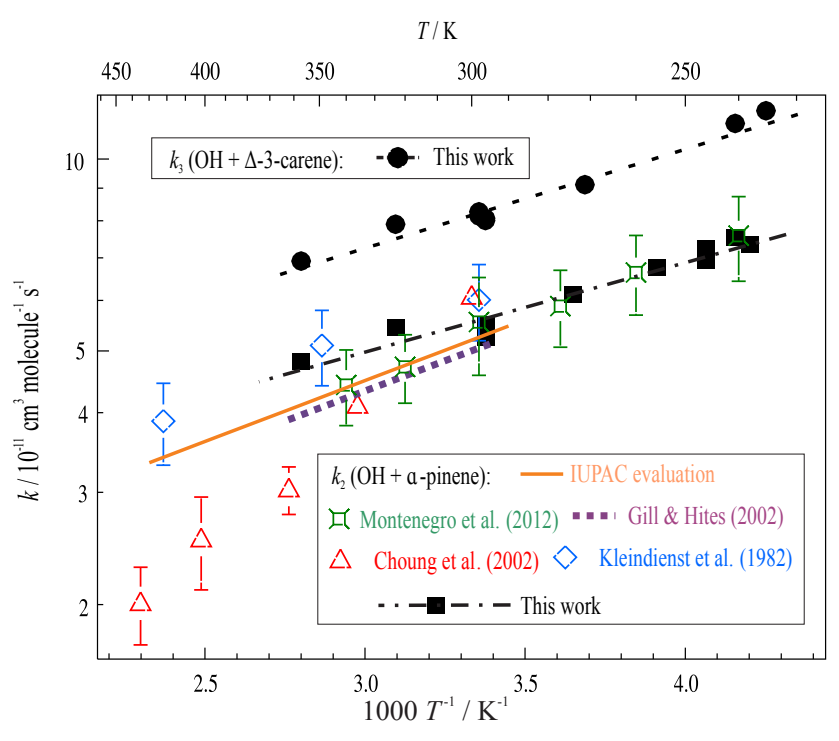

Figure 9. $k_{2}(T)$ and $k_{3}(T)$ from this work in Arrhenius format, together with previous experimental results and a $k_{2}(T)$ literature evaluation. Data from this work were fit with (Eq. 4) to yield $k_{2}$ $(238-357 \mathrm{~K})=(1.83 \pm 0.04) \times \exp \{(330 \pm 6) / T\}$ (represented by the black dot-dashed line $)$ and $k_{3}(235-357 \mathrm{~K})=(2.48 \pm 0.14) \times$ $\exp \{(357 \pm 17) / T\}$ (the black dashed line). Not displayed for reasons of clarity are literature datasets containing only ambient temperature $k_{2}$ results (these are listed in full in Table 3) and the 44 determinations of $k_{2}(297-364 \mathrm{~K})$ from Gill and Hites (2002), which are instead represented (purple dotted line) by a fit with (Eq. 4).

1976). The principal source of error in relative-rate determinations often derives from the choice of reference rate coefficient, required to convert an experimentally derived rate-coefficient ratio into an absolute rate coefficient. Confidence may be derived from the fact that five different reference reactions were used across the four published relative-rate (R2) studies. Absolute rate-coefficient determinations do not depend upon literature rates but do require an accurate knowledge of concentrations of the excess reagent ( $\alpha$-pinene or $\Delta$-3-carene). The present dataset used in situ optical absorption spectroscopy to accurately measure [ $\alpha$-pinene] and subsequently calculate an absolute $k_{2}$ $(296 \mathrm{~K})=(5.4 \pm 0.2) \times 10^{-11} \mathrm{~cm}^{3}$ molecule ${ }^{-1} \mathrm{~s}^{-1}$. Any er-

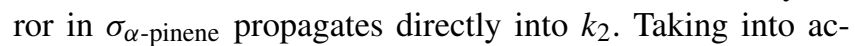
count potential systematic errors, principally the $5 \%$ uncertainty in $\sigma_{\alpha \text {-pinene }}$ (Sect. 3.1), a similar uncertainty in carrying out the optical measurements and $2 \%$ for sample purity, a total uncertainty of around $8 \%$ was calculated, so we calculate $k_{2}(296 \mathrm{~K})=(5.4 \pm 0.5) \times 10^{-11} \mathrm{~cm}^{3}$ molecule $\mathrm{e}^{-1} \mathrm{~s}^{-1}$. Within combined uncertainties there is reasonable agreement between this result and three previous absolute kinetic studies of (R2) (Chuong et al., 2002; Davis and Stevens, 2005; Kleindienst et al., 1982), all of which relied on manometric determinations of [ $\alpha$-pinene] to derive $k_{2}$. The IUPAC data evaluation panel currently recommends a value of $k_{2}$
$(298 \mathrm{~K})=5.3 \times 10^{-11} \mathrm{~cm}^{3}$ molecule $\mathrm{s}^{-1} \mathrm{~s}^{-1}$ (Ammann et al., 2016; Atkinson et al., 2006b), based on results from Atkinson et al. (1986), Gill and Hites (2002) and Kleindienst et al. (1982), with an associated $\Delta \log k_{2}=0.15$ or approximately $+40,-30 \%$. A re-evaluation taking into account the data from this work and from the recent (Montenegro et al., 2012 ) study yields (via a weighted mean) $k_{2}(298 \mathrm{~K})=5.4 \times$ $10^{-11} \mathrm{~cm}^{3}$ molecule $\mathrm{e}^{-1} \mathrm{~s}^{-1} ;$ a considerably smaller $\Delta \log \left(k_{2}\right)$ of 0.06 (around $\pm 15 \%$ ) would encompass all experimentally determined ambient temperature $k_{2}$ values.

IUPAC (Ammann et al., 2016; Atkinson et al., 2006b) uses the Arrhenius Eq. (4) to parameterize $k_{2}(T)$. A weighted fit of Eq. (4) to the data from this work yields $k_{2}(238-357 \mathrm{~K})=(1.83 \pm 0.04) \times 10^{-11} \exp \{(330 \pm$ 6) $/ T\} \mathrm{cm}^{3}$ molecule $\mathrm{e}^{-1} \mathrm{~s}^{-1}$, represented by the black dotdashed line in Fig. 9. Where data overlap ( 290 to $357 \mathrm{~K}$ ), these $k_{2}(T)$ lie within the large uncertainty $\left(\Delta \log k_{2}=0.15\right.$ at $\left.298 \mathrm{~K} ; \Delta \frac{E}{R}=200 \mathrm{~K}\right)$ reported by IUPAC for $k_{2}(290$ $430 \mathrm{~K})=1.2 \times 10^{-11} \exp \{440 / T\} \mathrm{cm}^{3}$ molecule ${ }^{-1} \mathrm{~s}^{-1}(\mathrm{Am}-$ mann et al., 2016; Atkinson et al., 2006b). Represented in Fig. 9 by the solid orange line, this recommendation was based on the results of Gill and Hites (2002) and Kleindienst et al. (1982) and is not in good agreement with the considerably smaller $k_{2}(T>350 \mathrm{~K})$ from Chuong et al. (2002). The reasons for this discrepancy are unclear. Chuong suggested that for their experimental conditions of $P=5$ Torr (He), observed $k(T>350 \mathrm{~K})$ may not be high-pressure limited values. However, no evidence for such a pressure dependence in $k_{2}$ was observed in subsequent relative-rate determinations of $k_{2}(T=340 \mathrm{~K}, P=1-5$ Torr He) from Montenegro et al. (2012). This discrepancy is not resolved by any results from the present study, as the apparatus did not permit experiments at sufficiently low pressures. The results presented in Table 2 and elsewhere would indicate that the values of $k_{2}$ obtained here at $P>7$ Torr and $T \approx 298 \mathrm{~K}$ were in the highpressure limit.

The current IUPAC recommendation (Ammann et al., 2016; Atkinson et al., 2006b) does not extend to important atmospheric temperatures lower than $290 \mathrm{~K}$, as no data were available when the evaluation was made. However, there are now two complementary datasets available. The absolute values from this work (see Table 2) and results from the most recent literature dataset (Montenegro et al., 2012) derived by relative-rate methods are in excellent agreement for $T<298 \mathrm{~K}$ conditions. It is clear from Fig. 9 that these two datasets could provide a basis for IUPAC to extend the recommendation for $k_{2}$ to $T<290 \mathrm{~K}$.

A similar analysis was applied to $k_{3}$, whereby potential systematic errors $\left(5 \%\right.$ each for $\sigma_{3}$ and the optical measurements, $1 \%$ for sample purity) were combined with the statistical uncertainties listed in Table 2 to yield an overall error estimate of around $8 \%$; hence $k_{3}(298 \mathrm{~K})=(8.2 \pm$ $0.6) \times 10^{-11} \mathrm{~cm}^{3}$ molecule ${ }^{-1} \mathrm{~s}^{-1}$. The only previous determination of $k_{3}$ was from Atkinson et al. (1986), who used 
the relative-rate method to obtain $k_{3}(294 \mathrm{~K})=(8.7 \pm 0.4) \times$ $10^{-11} \mathrm{~cm}^{3}$ molecule $\mathrm{s}^{-1}$. The good agreement between these two datasets, derived by very different experimental methods, is encouraging. It is clear from the data presented in Table 2 and displayed graphically in Fig. 9 that (R3) is characterized by negative or non-Arrhenius $k_{3}(T)$. A weighted Eq. (4) fit yields $k_{3}(235-357 \mathrm{~K})=(2.48 \pm 0.14) \times \exp \{(357 \pm$ 17) $/ T$ \}, depicted in Fig. 9 as the dashed black line. These results are the first reported for $k_{3}$ that were not obtained at room temperature. The non-Arrhenius behaviour observed is common for $\mathrm{OH}+$ monoterpene reactions that proceed predominantly by addition of $\mathrm{OH}$ to the unsaturated $\mathrm{C}=\mathrm{C}$ groups, with a smaller contribution $(\sim 10 \%)$ from direct abstraction of allyl-stabilized hydrogens (Peeters et al., 2001; Vereecken et al., 2007). To a first approximation therefore, (R2) and (R3) should proceed at quite similar rates, as the main reactive site (a methyl substituted endocyclic $\mathrm{C}=\mathrm{C}$ group) is common to $\alpha$-pinene and $\Delta$-3-carene. The data listed in Table 2 show that (R2) and (R3) are characterized by rate coefficients broadly consistent with this picture, i.e. non-Arrhenius $k(T)$ values approaching the collision limit of $10^{-10} \mathrm{~cm}^{3}$ molecule $\mathrm{s}^{-1}$. Note that as discussed above, in the reaction conditions employed here, addition of $\mathrm{OH}$ to such large (C10) molecules need not be characterized by any discernable pressure dependence. It is somewhat surprising, however, that the results from this work and from Atkinson et al. (1986) clearly demonstrate that $\mathrm{OH}$ reacts some $50 \%$ faster with $\Delta$-3-carene than with $\alpha$-pinene. This is unlikely to be due to any enhancement in abstraction rates as $\Delta$-3-carene has fewer allyl hydrogens available than does $\alpha$-pinene. The observed change in reactivity is presumably due to influence on the $\mathrm{C}=\mathrm{C}$ reactive site by the different location of the $\left(\mathrm{CH}_{3}\right)_{2} \mathrm{C}$ substituent in $\alpha$-pinene and $\Delta$-3-carene. Note that systematic attempts to parameterize $k_{2}$ via structure activity relationships have also failed at this level of detail (see e.g. the predicted $k_{2}$ and $k_{3}$ in Table 3 from Vereecken et al., 2007, and from Grosjean and Williams, 1992).

Finally, it should be reiterated that all $k_{2}$ and $k_{3}$ values reported in this work were determined via optically derived [monoterpene] and may more formally be considered as ratios such as $k_{2}(T) / \sigma_{\alpha \text {-pinene }}$ and $k_{3}(T) / \sigma_{\Delta-3 \text {-carene. Currently }}$ the database for $184.95 \mathrm{~nm}$ cross sections is sparse, consisting of only the results from this work and one other reported value for $\sigma_{\alpha \text {-pinene from Kubala et al. (2009). Any subsequent }}$ improvements in the database for $184.95 \mathrm{~nm}$ absorption cross sections for monoterpenes should be used to obtain up to date rate coefficients $k_{2}(T)$ and $k_{3}(T)$.

\section{Atmospheric implications and conclusions}

Breakdown of isoprene, initiated by reaction with the hydroxyl radical, is one of the most important oxidation reactions in the troposphere. The spectroscopic and kinetic results obtained in this work indicate that significant discrepan- cies between previous absolute and relative determinations of $k_{1}$ were most likely the result of using erroneous absorption cross sections to derive [isoprene] in absolute studies. The value of $k_{1}(297 \mathrm{~K})=(9.3 \pm 0.4) \times 10^{-11} \mathrm{~cm}^{3}$ molecule ${ }^{-1} \mathrm{~s}^{-1}$ reported here is in satisfactory agreement with many previous determinations using different methods and confirms an atmospheric lifetime for isoprene of a few hours in typical rainforest conditions.

Absolute rate coefficients were determined for the gasphase reactions of $\mathrm{OH}$ with two monoterpenes of atmospheric interest: $\alpha$-pinene (R2) and $\Delta$-3-carene (R3). At around ambient temperature, $k_{2}$ and $k_{3}$ were large and independent of bath-gas pressure (7-200 Torr) or composition $\left(\mathrm{N}_{2}\right.$ or air), indicating that these predominantly addition reactions are approaching their high-pressure limiting rate. The low-temperature rate coefficients derived in this work may be used to calculate atmospheric lifetimes for monoterpenes in realistic boreal forest conditions. Montenegro et al. (2012) used $T=277 \mathrm{~K}$ and $[\mathrm{OH}]=8.1 \times 10^{5}$ molecule $\mathrm{cm}^{-3}$ to calculate $\tau_{2}=\left\{k_{2}(T) \times[\mathrm{OH}]\right\}^{-1}=5.8 \mathrm{~h}$. The values of $T$ and $[\mathrm{OH}]$ used would appear appropriate for daytime boreal forest conditions during a springtime emission event (Back et al., 2005). When using the absolute value of $k_{2}(277 \mathrm{~K})$ from this work, the calculated value of $\tau_{2}=5.8 \mathrm{~h}$ is unchanged, a result that significantly enhances confidence in this parameter. We note that similar calculations (using mixing ratios of $30 \mathrm{ppb}$ for $\mathrm{O}_{3}$ and kinetic data from IUPAC) demonstrate that $\alpha$-pinene is oxidized by $\mathrm{O}_{3}$ at a very similar rate. The publication in this work of the first $k_{3}(T)$ allows the calculation of realistic atmospheric lifetimes for $\Delta$-3-carene with respect to $(\mathrm{R} 3)$. Using $[\mathrm{OH}]=8.1 \times 10^{5}$ molecule $\mathrm{cm}^{-3}$ and $k_{3}(277 \mathrm{~K})=9.0 \times 10^{-11} \mathrm{~cm}^{3}$ molecule ${ }^{-1} \mathrm{~s}^{-1}$ from this work, $\tau_{3}=3.8 \mathrm{~h}$ was calculated. The corresponding calculation (again using $30 \mathrm{ppb}$ of $\mathrm{O}_{3}$ and kinetic data from IUPAC) results in a loss rate some 2.5 slower for $\Delta$-3-carene with $\mathrm{O}_{3}$. These results demonstrate that the dominant daytime loss process for $\Delta$-3-carene is reaction with $\mathrm{OH}(\mathrm{R} 3)$.

Data availability. The kinetic data are available in tables in the paper; requests to the authors for raw data would be considered on a case-by-case basis depending on proposed usage.

Author contributions. JNC and TJD designed all experiments and planned the overall project; KD conducted the spectroscopic experiments; TJD and CBMG conducted the kinetic experiments; TJD prepared the manuscript with contributions from all authors.

Competing interests. The authors declare that they have no conflict of interest. 
Acknowledgements. The authors thank Gerhard Schuster for everexcellent technical support, Jonathan Williams and Luc Vereecken for helpful discussions regarding the monoterpene reactions and the Max Planck Society for support via a research fellowship.

Edited by: Thorsten Bartels-Rausch

Reviewed by: Anthony Hynes and one anonymous referee

\section{References}

Atkinson, R., Aschmann, S. M., and Pitts, J. N.: Rate constants for the gas-phase reactions of the OH-radical with a series of monoterpenes at $298+/-1 \mathrm{~K}$, Int. J. Chem. Kinet., 18, 287299, https://doi.org/10.1002/kin.550180303, 1986.

Atkinson, R. and Arey, J.: Gas-phase tropospheric chemistry of biogenic volatile organic compounds: a review, Atmos. Environ., 37, S197-S219, https://doi.org/10.1016/s1352-2310(03)00391$1,2003$.

Atkinson, R., Baulch, D. L., Cox, R. A., Crowley, J. N., Hampson, R. F., Hynes, R. G., Jenkin, M. E., Rossi, M. J., Troe, J., and IUPAC Subcommittee: Evaluated kinetic and photochemical data for atmospheric chemistry: Volume II - gas phase reactions of organic species, Atmos. Chem. Phys., 6, 3625-4055, https://doi.org/10.5194/acp-6-3625-2006, 2006a.

Atkinson, R., Baulch, D. L., Cox, R. A., Crowley, J. N., Hampson, R. F., Hynes, R. G., Jenkin, M. E., Rossi, M. J., Troe, J., and IUPAC Subcommittee: Evaluated kinetic and photochemical data for atmospheric chemistry: Volume II - gas phase reactions of organic species, Atmos. Chem. Phys., 6, 3625-4055, https://doi.org/10.5194/acp-6-3625-2006, 2006b.

Back, J., Hari, P., Hakola, H., Juurola, E., and Kulmala, M.: Dynamics of monoterpene emissions in Pinus sylvestris during early spring, Boreal Environ. Res., 10, 409-424, 2005.

Baptista, L., Francisco, L. F., Dias, J. F., da Silva, E. C., dos Santos, C. V. F., de Mendonca, F. S. G., and Arbilla, G.: Theoretical study of Delta-3-(+)-carene oxidation, Phys. Chem. Chem. Phys., 16, 19376-19385, https://doi.org/10.1039/c4cp02627f, 2014.

Butler, T. M., Taraborrelli, D., Brühl, C., Fischer, H., Harder, H., Martinez, M., Williams, J., Lawrence, M. G., and Lelieveld, J.: Improved simulation of isoprene oxidation chemistry with the ECHAM5/MESSy chemistry-climate model: lessons from the GABRIEL airborne field campaign, Atmos. Chem. Phys., 8, 4529-4546, https://doi.org/10.5194/acp-8-4529-2008, 2008.

Campuzano-Jost, P., Williams, M. B., D’Ottone, L., and Hynes, A. J.: Kinetics and mechanism of the reaction of the hydroxyl radical with $\mathrm{H}(8)$-isoprene and $\mathrm{D}(8)$-isoprene: Isoprene absorption cross sections, rate coefficients, and the mechanism of hydroperoxyl radical production, J. Phys. Chem. A, 108, 15371551, https://doi.org/10.1021/jp0363601, 2004.

Chuong, B. and Stevens, P. S.: Kinetic study of the $\mathrm{OH}$ plus isoprene and $\mathrm{OH}$ plus ethylene reactions between 2 and 6 torr and over the temperature range 300-423 K, J. Phys. Chem. A, 104, 52305237, https://doi.org/10.1021/jp993613a, 2000.

Chuong, B., Davis, M., Edwards, M., and Stevens, P. S.: Measurements of the kinetics of the $\mathrm{OH}$ plus alpha-pinene and $\mathrm{OH}$ plus beta-pinene reactions at low pressure, Int. J. Chem. Kinet., 34, 300-308, https://doi.org/10.1002/kin.10058, 2002.
Dash, M. R., Balaganesh, M., and Rajakumar, B.: Rate coefficients for the gas-phase reaction of $\mathrm{OH}$ radical with alpha-pinene: an experimental and computational study, Mol. Phys., 112, 14951511, https://doi.org/10.1080/00268976.2013.840395, 2014.

Davis, M. E. and Stevens, P. S.: Measurements of the kinetics of the OH-initiated oxidation of alpha-pinene: Radical propagation in the $\mathrm{OH}$ plus alpha-pinene $+\mathrm{O}_{2}+\mathrm{NO}$ reaction system, Atmos. Environ., 39, 1765-1774, https://doi.org/10.1016/j.atmosenv.2004.09.068, 2005.

Dillon, T. J., Tucceri, M. E., Dulitz, K., Horowitz, A., Vereecken, L., and Crowley, J. N.: Reaction of Hydroxyl Radicals with $\mathrm{C}_{4} \mathrm{H}_{5} \mathrm{~N}$ (Pyrrole): Temperature and Pressure Dependent Rate Coefficients, J. Phys. Chem. A, 116, 6051-6058, https://doi.org/10.1021/jp211241x, 2012.

Fan, J. W., Zhao, J., and Zhang, R. Y.: Theoretical study of OH addition to alpha-pinene and beta-pinene, Chem. Phys. Lett., 411, 1-7, https://doi.org/10.1016/j.cplett.2005.05.122, 2005.

Gill, K. J. and Hites, R. A.: Rate constants for the gas-phase reactions of the hydroxyl radical with isoprene, alpha- and betapinene, and limonene as a function of temperature, J. Phys. Chem. A, 106, 2538-2544, https://doi.org/10.1021/jp013532q, 2002.

Goldstein, A. H. and Galbally, I. E.: Known and unexplored organic constituents in the earth's atmosphere, Environ. Sci. Technol., 41, 1514-1521, https://doi.org/10.1021/es072476p, 2007.

Grosjean, D. and Williams, E. L.: Environmental persistence of organic-compounds estimated from structure reactivity and linear free-energy relationships unsaturated aliphatics, Atmos. Environ. A-Gen., 26, 1395-1405, https://doi.org/10.1016/09601686(92)90124-4, 1992.

Guenther, A., Hewitt, C. N., Erickson, D., Fall, R., Geron, C., Graedel, T., Harley, P., Klinger, L., Lerdau, M., McKay, W. A., Pierce, T., Scholes, B., Steinbrecher, R., Tallamraju, R., Taylor, J., and Zimmerman, P.: A Global-Model of Natural Volatile Organic-Compound Emissions, J. Geophys. Res.-Atmos., 100, 8873-8892, 1995.

Haase, K. B., Jordan, C., Mentis, E., Cottrell, L., Mayne, H. R., Talbot, R., and Sive, B. C.: Changes in monoterpene mixing ratios during summer storms in rural New Hampshire (USA), Atmos. Chem. Phys., 11, 11465-11476, https://doi.org/10.5194/acp-1111465-2011, 2011.

Hakola, H., Tarvainen, V., Laurila, T., Hiltunen, V., Hellen, H., and Keronen, P.: Seasonal variation of VOC concentrations above a boreal coniferous forest, Atmos. Environ., 37, 1623-1634, https://doi.org/10.1016/s1352-2310(03)00014-1, 2003.

Hakola, H., Hellén, H., Hemmilä, M., Rinne, J., and Kulmala, M.: In situ measurements of volatile organic compounds in a boreal forest, Atmos. Chem. Phys., 12, 11665-11678, https://doi.org/10.5194/acp-12-11665-2012, 2012.

Heijari, J., Blande, J. D., and Holopainen, J. K.: Feeding of large pine weevil on Scots pine stem triggers localised bark and systemic shoot emission of volatile organic compounds, Environ. Exp. Bot., 71, 390-398, https://doi.org/10.1016/j.envexpbot.2011.02.008, 2011.

Hellén, H., Hakola, H., Pystynen, K.-H., Rinne, J., and Haapanala, S.: $\mathrm{C}_{2}-\mathrm{C}_{10}$ hydrocarbon emissions from a boreal wetland and forest floor, Biogeosciences, 3, 167-174, https://doi.org/10.5194/bg-3-167-2006, 2006. 
IUPAC: Task Group on Atmospheric Chemical Kinetic Data Evaluation: http://iupac.pole-ether.fr/index.html, last access: 14 June 2017, 2016.

Karunanandan, R., Holscher, D., Dillon, T., Horowitz, A., Crowley, J., Vereecken, L., and Peeters, J.: Reaction of HO with glycolaldehyde, $\mathrm{HOCH}_{2} \mathrm{CHO}$ : Rate coefficients (240$362 \mathrm{~K})$ and mechanism, J. Phys. Chem. A, 111, 897-908, https://doi.org/10.1021/jp0649504, 2007.

Kleindienst, T. E., Harris, G. W., and Pitts, J. N.: Rates and temperature dependences of the reaction of $\mathrm{OH}$ with isoprene, its oxidation-products, and selected terpenes Environ. Sci. Technol., 16, 844-846, https://doi.org/10.1021/es00106a004, 1982.

Kubala, D., Drage, E. A., Al-Faydhi, A. M. E., Kocisek, J., Papp, P., Matejcik, V., Mach, P., Urban, J., Limao-Vieira, P., Hoffmann, S. V., Matejcik, S., and Mason, N. J.: Electron impact ionisation and UV absorption study of alphaand beta-pinene, Int. J. Mass Spectrom., 280, 169-173, https://doi.org/10.1016/j.ijms.2008.07.035, 2009.

Kubistin, D., Harder, H., Martinez, M., Rudolf, M., Sander, R., Bozem, H., Eerdekens, G., Fischer, H., Gurk, C., Klüpfel, T., Königstedt, R., Parchatka, U., Schiller, C. L., Stickler, A., Taraborrelli, D., Williams, J., and Lelieveld, J.: Hydroxyl radicals in the tropical troposphere over the Suriname rainforest: comparison of measurements with the box model MECCA, Atmos. Chem. Phys., 10, 9705-9728, https://doi.org/10.5194/acp10-9705-2010, 2010.

Lelieveld, J., Butler, T., Crowley, J., Dillon, T., Fischer, H., Ganzeveld, L., Harder, H., Lawrence, M., Martinez, M., Taraborrelli, D., and Williams, J.: Atmospheric oxidation capacity sustained by a tropical forest, Nature, 452, 737-740, https://doi.org/10.1038/nature06870, 2008.

Martinez, M., Harder, H., Kubistin, D., Rudolf, M., Bozem, H., Eerdekens, G., Fischer, H., Klüpfel, T., Gurk, C., Königstedt, R., Parchatka, U., Schiller, C. L., Stickler, A., Williams, J., and Lelieveld, J.: Hydroxyl radicals in the tropical troposphere over the Suriname rainforest: airborne measurements, Atmos. Chem. Phys., 10, 3759-3773, https://doi.org/10.5194/acp10-3759-2010, 2010.

Martins, G., Ferreira-Rodrigues, A. M., Rodrigues, F. N., de Souza, G. G. B., Mason, N. J., Eden, S., Duflot, D., Flament, J. P., Hoffmann, S. V., Delwiche, J., Hubin-Franskin, M. J., and Limao-Vieira, P.: Valence shell electronic spectroscopy of isoprene studied by theoretical calculations and by electron scattering, photoelectron, and absolute photoabsorption measurements, Phys. Chem. Chem. Phys., 11, 11219-11231, https://doi.org/10.1039/b916620c, 2009.

McGivern, W. S., Suh, I., Clinkenbeard, A. D., Zhang, R. Y., and North, S. W.: Experimental and computational study of the $\mathrm{OH}$-isoprene reaction: Isomeric branching and lowpressure behavior, J. Phys. Chem. A, 104, 6609-6616, https://doi.org/10.1021/jp001163c, 2000.

Montenegro, A., Ishibashi, J. S. A., Lam, P., and Li, Z. J.: Kinetics Study of Reactions of alpha-Pinene and betaPinene with Hydroxyl Radical at 1-8 Torr and 240340 K Using the Relative Rate/Discharge Flow/Mass Spectrometry Method, J. Phys. Chem. A, 116, 12096-12103, https://doi.org/10.1021/jp307718m, 2012.

Ng, N. L., Brown, S. S., Archibald, A. T., Atlas, E., Cohen, R. C., Crowley, J. N., Day, D. A., Donahue, N. M., Fry, J. L.,
Fuchs, H., Griffin, R. J., Guzman, M. I., Herrmann, H., Hodzic, A., Iinuma, Y., Jimenez, J. L., Kiendler-Scharr, A., Lee, B. H., Luecken, D. J., Mao, J., McLaren, R., Mutzel, A., Osthoff, H. D., Ouyang, B., Picquet-Varrault, B., Platt, U., Pye, H. O. T., Rudich, Y., Schwantes, R. H., Shiraiwa, M., Stutz, J., Thornton, J. A., Tilgner, A., Williams, B. J., and Zaveri, R. A.: Nitrate radicals and biogenic volatile organic compounds: oxidation, mechanisms, and organic aerosol, Atmos. Chem. Phys., 17, 2103-2162, https://doi.org/10.5194/acp-17-2103-2017, 2017.

Nölscher, A. C., Williams, J., Sinha, V., Custer, T., Song, W., Johnson, A. M., Axinte, R., Bozem, H., Fischer, H., Pouvesle, N., Phillips, G., Crowley, J. N., Rantala, P., Rinne, J., Kulmala, M., Gonzales, D., Valverde-Canossa, J., Vogel, A., Hoffmann, T., Ouwersloot, H. G., Vilà-Guerau de Arellano, J., and Lelieveld, J.: Summertime total $\mathrm{OH}$ reactivity measurements from boreal forest during HUMPPA-COPEC 2010, Atmos. Chem. Phys., 12, 8257-8270, https://doi.org/10.5194/acp-12-8257-2012, 2012.

Park, J., Jongsma, C. G., Zhang, R. Y., and North, S. W.: OH/OD initiated oxidation of isoprene in the presence of $\mathrm{O}_{2}$ and NO, J. Phys. Chem. A., 108, 10688-10697, https://doi.org/10.1021/jp040421t, 2004.

Peeters, J., Vereecken, L., and Fantechi, G.: The detailed mechanism of the $\mathrm{OH}$-initiated atmospheric oxidation of alpha-pinene: a theoretical study, Phys. Chem. Chem. Phys., 3, 5489-5504, https://doi.org/10.1039/b106555f, 2001.

Peeters, J., Boullart, W., Pultau, V., Vandenberk, S., and Vereecken, L.: Structure-activity relationship for the addition of $\mathrm{OH}$ to (poly)alkenes: Site-specific and total rate constants, J. Phys. Chem. A, 111, 1618-1631, https://doi.org/10.1021/jp066973o, 2007.

Renbaurn-Wolff, L. and Smith, G. D.: "Virtual Injector" Flow Tube Method for Measuring Relative Rates Kinetics of GasPhase and Aerosol Species, J. Phys. Chem. A, 116, 6664-6674, https://doi.org/10.1021/jp303221w, 2012.

Siese, M., Koch, R., Fittschen, C., and Zetzsch, C.: Cycling of OH in the Reaction Systems Toluene $/ \mathrm{O}_{2} / \mathrm{NO}$ and Acetylene $/ \mathrm{O}_{2}$ and the Addition of $\mathrm{OH}$ to Isoprene, in: Proceedings of the EUROTRAC Symposium '94, edited by: Borrell, P. M., Borrell, P., Cvitaš, T., and Seiler, W., SPB Aacademic Publishing, Den Haag, The Netherlands, 115-119, 1994.

Singh, S. and Li, Z. J.: Kinetics investigation of $\mathrm{OH}$ reaction with isoprene at $240-340 \mathrm{~K}$ and $1-3$ Torr using the relative rate/discharge flow/mass spectrometry technique, J. Phys. Chem. A, 111, 11843-11851, https://doi.org/10.1021/jp074148h, 2007.

Smialek, M. A., Hubin-Franskin, M. J., Delwiche, J., Duflot, D., Mason, N. J., Vronning-Hoffmann, S., de Souza, G. G. B., Rodrigues, A. M. F., Rodrigues, F. N., and Limao-Vieira, P.: Limonene: electronic state spectroscopy by high-resolution vacuum ultraviolet photoabsorption, electron scattering, $\mathrm{He}(\mathrm{I})$ photoelectron spectroscopy and ab initio calculations, Phys. Chem. Chem. Phys., 14, 2056-2064, https://doi.org/10.1039/c2cp22847e, 2012.

Spangenberg, T., Kohler, S., Hansmann, B., Wachsmuth, U., Abel, B., and Smith, M. A.: Low-temperature reactions of $\mathrm{OH}$ radicals with propene and isoprene in pulsed laval nozzle expansions, J. Phys. Chem. A, 108, 7527-7534, https://doi.org/10.1021/jp031228m, 2004.

Stone, D., Evans, M. J., Edwards, P. M., Commane, R., Ingham, T., Rickard, A. R., Brookes, D. M., Hopkins, J., Leigh, R. J., Lewis, 
A. C., Monks, P. S., Oram, D., Reeves, C. E., Stewart, D., and Heard, D. E.: Isoprene oxidation mechanisms: measurements and modelling of $\mathrm{OH}$ and $\mathrm{HO}_{2}$ over a South-East Asian tropical rainforest during the OP3 field campaign, Atmos. Chem. Phys., 11, 6749-6771, https://doi.org/10.5194/acp-11-6749-2011, 2011.

Vereecken, L., Muller, J. F., and Peeters, J.: Low-volatility poly-oxygenates in the $\mathrm{OH}$-initiated atmospheric oxidation of alpha-pinene: impact of non-traditional peroxyl radical chemistry, Phys. Chem. Chem. Phys., 9, 5241-5248, https://doi.org/10.1039/b708023a, 2007.

Williams, J., Crowley, J., Fischer, H., Harder, H., Martinez, M., Petäjä, T., Rinne, J., Bäck, J., Boy, M., Dal Maso, M., Hakala, J., Kajos, M., Keronen, P., Rantala, P., Aalto, J., Aaltonen, H., Paatero, J., Vesala, T., Hakola, H., Levula, J., Pohja, T., Herrmann, F., Auld, J., Mesarchaki, E., Song, W., Yassaa, N., Nölscher, A., Johnson, A. M., Custer, T., Sinha, V., Thieser, J., Pouvesle, N., Taraborrelli, D., Tang, M. J., Bozem, H., Hosaynali-Beygi, Z., Axinte, R., Oswald, R., Novelli, A., Kubistin, D., Hens, K., Javed, U., Trawny, K., Breitenberger, C., Hidalgo, P. J., Ebben, C. J., Geiger, F. M., Corrigan, A. L., Russell, L. M., Ouwersloot, H. G., Vilà-Guerau de Arellano, J., Ganzeveld, L., Vogel, A., Beck, M., Bayerle, A., Kampf, C. J., Bertelmann, M., Köllner, F., Hoffmann, T., Valverde, J., González, D., Riekkola, M.-L., Kulmala, M., and Lelieveld, J.: The summertime Boreal forest field measurement intensive (HUMPPA-COPEC-2010): an overview of meteorological and chemical influences, Atmos. Chem. Phys., 11, 10599-10618, https://doi.org/10.5194/acp-11-10599-2011, 2011.
Winer, A. M., Lloyd, A. C., Darnall, K. R., and Pitts, J. N.: Relative rate constants for reaction of hydroxyl radical with selected ketones, chloroethenes, and monoterpene hydrocarbons, J. Phys. Chem., 80, 1635-1639, https://doi.org/10.1021/j100555a024, 1976.

Yassaa, N., Peeken, I., Zollner, E., Bluhm, K., Arnold, S., Spracklen, D., and Williams, J.: Evidence for marine production of monoterpenes, Environ. Chem., 5, 391-401, https://doi.org/10.1071/en08047, 2008. 